UJBM, Vol. 8, No. 1, January - June 2009, pp 47-93

ISSN 0975-3311 | https://doi.org/10.12725/ujbm.14.6

\title{
CONTRARIAN AND MOMENTUM STRATEGIES IN THE INDIAN STOCK MARKET
}

\section{Anirban Ghatak*}

Researchers worldwide have studied contrarian and momentum strategies as a mechanism to make super normal profits in the capital markets. Contrarians believe that markets overreact to a piece of news and subsequently a correction fakes place, hence stock or portfolio price doesn't reflect true value at all times. Therefore going against the market (buy the loser and sell the winner) offers a viable strategy to earn super normal refurns. A plausible explanation to the contrarian hypothesis can be offered in terms of human behavior. Humans have short memory and they tend to make decisions on the latest information. Thus people unknowingly give more weightage to a recent piece of news. As the time passes, investors realize the true effect of the news on the firm and the price correction takes place.

On the other hand momentumists believe that markets under react to a piece of news. Market is cautious and it starts moving up or down depending on the news, but it takes time to evaluate the impact of the

* Christ University Instifute of Management, Bangalore-29. 


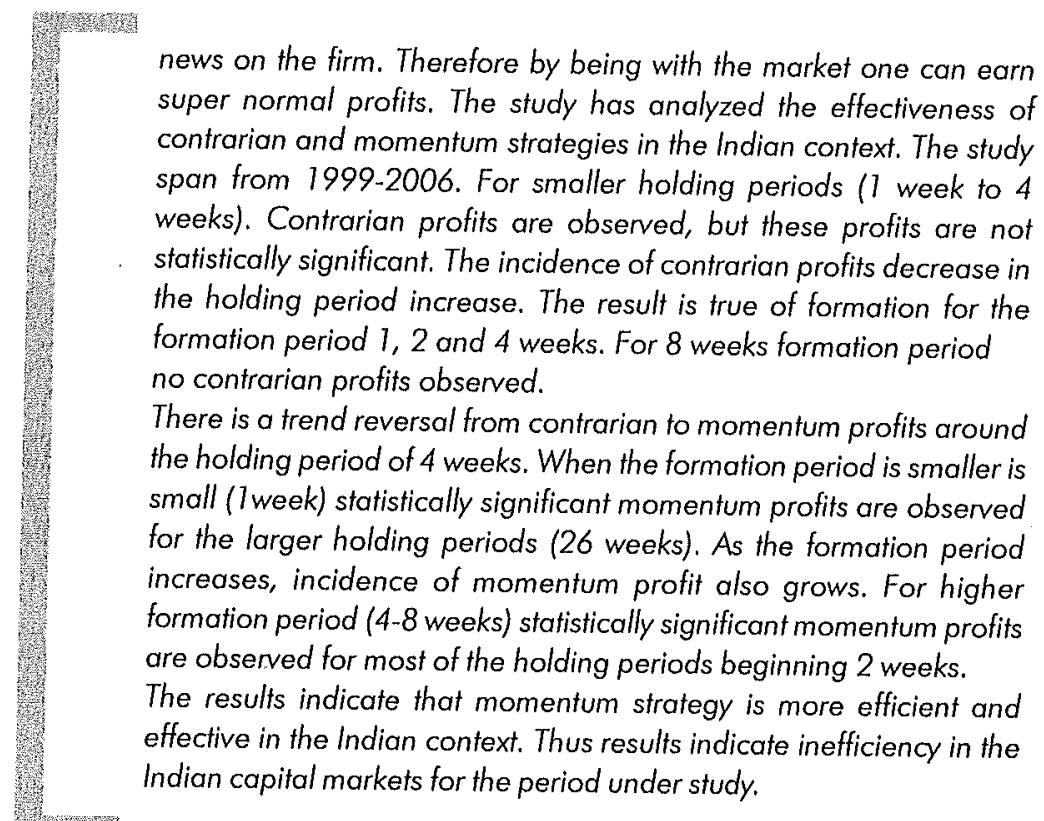

\section{Introduction}

As man is a social animal so his decision- making process is influenced by sentiments of others as well. All economic theories start with the assumption of rationality, but how far is it correct? Cognitive biases can lead an individual from rational decision- making. While investing in stock markets such biases lead many market participants to behave in a similar manner.

Internet boom is an example of the herd mentality of human beings. Herding behavior leads to overreaction to information, which can be a source of contrarian profits. More inefficient the capital market, greater is the time taken for price correction to happen. Thus analysis of contrarian profits over a period of time can give insight into level of capital market efficiency.

\section{Contrarian strategy}

Contrarian strategy essentially means doing reverse of what the market does. Hence under contrarian investment strategy, past losers are bought and past winners are shorted or sold. 
Contrarian strategy requires an active intervention of a portfolio manager in the form of portfolio rebalancing. Hence contrarian strategy of investing in the capital markets is an active portfolio management strategy. Many ways have been suggested for constructing a contrarian portfolio.

Low P/E Technique is one of the oldest and best documented contrarian strategies. To implement this strategy, stocks are sorted in descending order on the basis of their price- earning multiple and the stocks, which are towards the tail are bought. The premise of the P/E technique is that the markets are inefficient and these stocks are undervalued in the market. It is important to note that this strategy requires rebalancing of the portfolio because price earning multiple of the stocks keeps on changing.

Another strategy is to buy stocks with low price to book ratio. Market is normally bullish on high price to book value stocks, hence a contrarian goes long on stocks with low price to book ratio.

Cash flow in a company is roughly the sum of profits and depreciation. Price to cash flow strategy suggests that stocks with low price to cash flow should be bought while stocks with high price to cash flow should be shorted.

All three price to value strategies mentioned above require rebalancing of the portfolio, but each change has transaction cost which many affect overall profitability of any such strategy.

Technical Analysis and Fundamental Analysis also suggest some contrarian strategies. Fundamentalists look at economic or managerial data that is innate to the performance of the company that they are studying. Key financial measure like sales, earnings, cash balances, leverage and profit margins are used to gauge performance of the company. Fundamentalists also gauge other qualitative data such as new products and marketing initiatives. Fundamental analysis use these facts to estimate what a company might earn in the future and thus determine if the stock is overvalued, undervalued or correctly or correctly priced.

Following figure illustrates contrarian view of the world and how contrarian strategy can be applied 


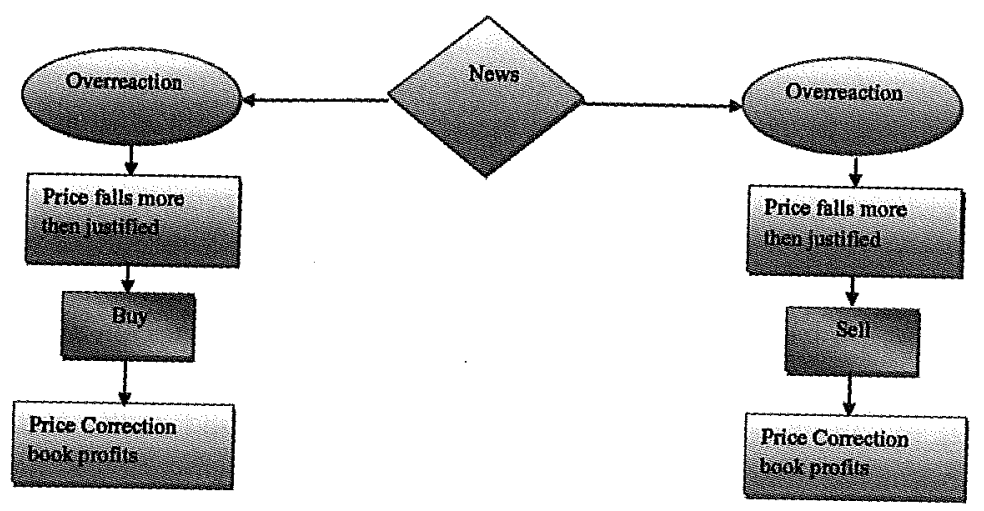

Figure 1: Contrarian strategy

\section{Momentum strategies}

Momentum strategies believe that markets are slow to react and if a stock is strengthening, it would increase further because market is cautious and the price doesn't adjust to information instantaneously. On the other hand if a stock is weakening, it will go down further because market takes time to readjust to the information. Hence there is no rational to go long on the stock, which is declining.

Under the momentum strategy, past winners are bought and past losers are shorted or sold. Figure given below explains the momentumist's world view.

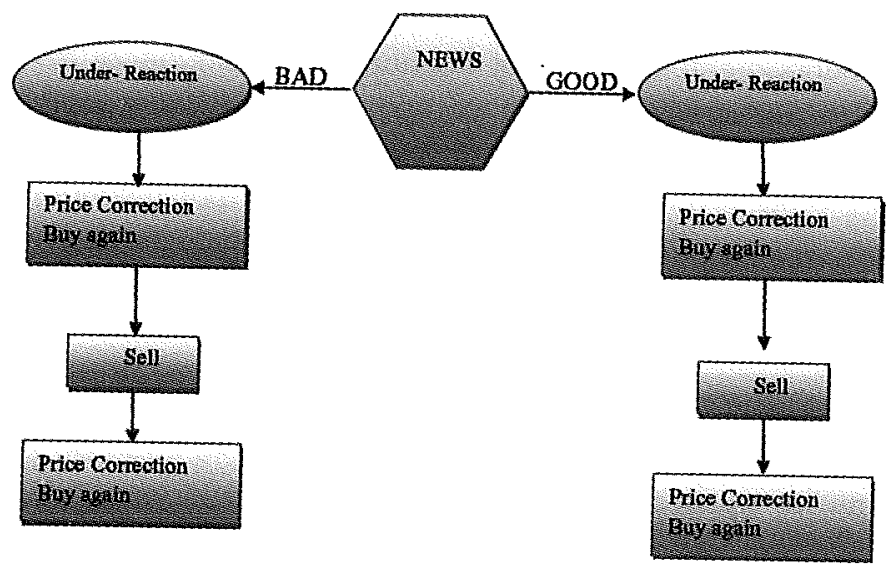

Figure 2: Momentum strategies 
A momentum investor purchases stocks that are out performing their industries or the ,market and sells them when they perform badly. This has been the established strategy for most of the financial managers throughout the world. There are two theories propound for the momentum strategies, one is based on human behavior and another based on the capital market efficiency. Behaviorists say that momentum profits are due to market inefficiencies and the result from stock prices irrational reactions to information and investors' herding behavior. The market efficiency camp on the other hand, argues that time- varying common factors and/or data mining lead to the existence of intermediate- term momentum profits. According to this explanation, the abnormal returns of the momentum strategies are attributable to common factors that are not accounted for in, for example, CAPM or the three- factor model.

\section{Literature Review}

Studies on Contrarian and Momentum strategies have been carried out in different markets. Joseph Kang, Ming-hua Liu and Sophie Xiaoyan Ni studied in the Chinese capital markets. The study found statistically significant Contrarian profits on short horizons and statistically significant Momentum profits on the immediate horizon. The study also qualifies that China is one of the few countries where stock markets are negatively correlated with the United States Markets. Also in China reliable information on listed companies is not readily available, hence they are driven by rumors and investor sentiment. They argue that the overreaction to the firm specific information is single most important determinant of contrarian profits and negative determinant of momentum profits.

Another study on Malaysian markets examined 3, 6 and 12 months contrarian investment study with and without the control of the firm size in Kuala Lumpur stock exchange from January 1987 to December 1999. The findings indicate evidence in favor of the contrarian investment strategy with significant returns reversal pattern for both winner and loser portfolios during normal market periods. However, during the bullish and bearish periods, the results indicate evidence of price continuation and contraction respectively for both winner and loser portfolios during normal market periods. The study argues the importance of understanding investor psychology in the pursuit of superior returns in the Malaysian markets. During the bullish period due to high investor sentiment stock prices of the winner and loser 
stocks are pushed up. Investors try to make windfall gains and they downplay caution. During the bearish period when investor sentiment is down, any bad news is punished. Due to social comparisons investor find it difficult to implement contrarian strategy in such a market. This study believes in the hypothesis that investors in emerging markets behave significantly different from the investors in developed markets.

Jim Y.F.Chin, Andrew K. Prevost and Aron A Gottesman studied contrarian investment strategy in small capitalization market. They chose New Zealand for their study. New Zealand represents $0.4 \%$ of the world equity and to 10 firms represents around three- quarters of the market thus New Zealandis na imperfectly competitive market as investors have few options. Chin, Prevost and Gottesman further argue that noise trading is more persistent in imperfectly competitive markets, thus the time the stocks take to return to theit fundamental value should be longer in imperfectly competitive markets. They find that the time required for value strategy ( buying under-priced securities) to pay off is longer in illiquid markets like New Zealand when compared to Japanese markets of the US markets.

Willamson N. Goetzmann and Massimo Massa studied 91000 accounts an S\&P 500 index fund over a two year horizon and found that within this larger group there is a subgroup of investors who consistently react to price changes. Goetzmann and Massa found a group of investors who act contrarians with respect to market volatility. This group of investors who act contrarians with respect to market volatility. This group of investors can be thought of as active- mean variance optimizers who increase holdings in risky assets when variance is low and decrease when holdings when variance is high. Thus this work discusses individual investor behavior instead of portfolio manager behavior.

Jegadeesh and Titman find evidence that strategies which buy stocks that have performed well in the past and sell stocks that have performed poorly in the past generate significant positive returns over 3-12 months holding periods. They argue that profitability of these strategies is not due to their systematic risk or delayed price reactions to common factors. However, part of the abnormal returns generated in the first year after portfolio formation dissipates in the following two years.

Lo and Mackinlay identify size related lead-lag rather than an overreaction to information as the main source of contrarian profits in the short horizons. 
They found a large positive cross-serial covariance between the returns of small stocks and lagged returns of large stocks (but, weak crossautocorrelation between returns of larger stocks and lagged small stocks)

\section{Data and Methodology}

To do the analysis 27 stocks from Niffy 50 stocks is selected. The stocks chosen are highly liquid stocks that are actively traded and have been market leaders and/or industry leaders. These stocks are less prone to manipulation by rogue traders due to their large market capitalization, fairly large holdings of institutional investors and wide coverage of stocks by brokerage houses and media. Weekly stock price data for these 27 stocks for the period 1999-2006 has been obtained from EBSCO database and website of NSE.

The contrarian investment strategy is formulated by selling the "winner" stocks and buying the "loser" stocks during the "formation period", among the selected 27 stocks. The returns of this portfolio are observed for a period of upto 26 weeks (Holding period)

Some terms need to be defined before we move forward with the description of the methodology.

\section{Formation Period (F)}

A period for which a stock or a stock portfolio is observed to make buy or sell decision on the basis of returns in the observed period. For example a formation period of 1 week means that the stock returns on the 27 stocks fro one week is used to arrive at the winners and losers. The formation period value has been taken as $1,2,4$ and 8 weeks.

\section{Holding Period $(\mathbf{H})$}

A period for which a stock or a stock portfolio returns is observed. The holding period varies from 1 to 26 weeks. Returns of Contrarian, loser and winner portfolio are observed during the holding period.

We have chosen holding periods and formation period not to be too long because people forget the information source after a period of time. 
Hence over the long periods it was difficult to attribute returns to these strategies.

\section{Winner Stocks (W)}

Stocks that beat the median market average are Winner stocks. For the purpose of the study, top five stocks among the 27 stocks under consideration form winner portfolio.

\section{Loser Stocks (L)}

Stocks that earn below the median market average market returns are referred to as loser portfolios. For the purpose of study, bottom five stocks among the 27 stocks under consideration form the loser portfolio.

\section{Contrarian Portfolio}

Portfolio formed by shorting the winner stocks and buying the loser stocks on an equal value weighted basis.

\section{Momentum Portfolio}

Portfolio formed by shorting the loser stocks and buying the winner stocks on an equal value weighted basis. By definition the returns on momentum portfolio and contrarian portfolio are equal in magnitude but opposite in nature.

\section{Portfolio}

Single stock analysis cannot yield any meaningful results because "noise" effects are difficult to control in single stock portfolio. Hence portfolio of 5 stocks is formed from the set of 27 scripts from Niffy 50 .

\section{War}

Weekly Annualized Return is defined as the annualized return obtained by the porffolio for various holding periods. For example if a portfolio gives 
a return of ' $x$ ' for a holding period of 2 weeks. WAR is defined as 26 times ' $x$ '.

\section{Portfolio Formation}

Following are the steps in the portfolio formation:

1. Rank the stock return for the selected 27 stocks in the past F-week portfolio formation period in a descending order. $F$ can take value $1,2,4$ and 8 weeks. Based on the ranking, two equal sized quintile portfolios are formed, one comprising top five stocks and the other comprising bottom five stocks.

2. The quintile portfolio with the highest stock returns is the winner portfolio, whereas the quintile portfolio with the lowest return is the loser.

3. An equal-weighted average return for each quintile portfolio over the next $\mathrm{H}$ - week holding period, as well as the difference between returns of the loser and the winner portfolios during the $\mathrm{H}$-week holding period, is calculated.

4. Contrarian returns are calculated as returns arising from going long on the loser portfolio and short on winner portfolio for various holdings. These returns are simple annualized to arrive at weekly Annualized Returns (WAR).

5. Momentum returns are calculated as returns arising from going short on loser portfolio and going long on winner portfolio for various holding periods. These returns are simple annualized to arrive at WAR

6. Holding period is varied from 1 to 26 weeks.

7. Rollover is done for 26 weeks to cover 52 weeks period.

8. The process is repeated for the years 1994-2001 with formation period of $1,2,4$ and 8 weeks respectively. 


\section{Hypothesis}

Following hypothesis have been formed to test contrarian and momentum strategies.

Hypothesis 1:

$H_{0}$ : Proportion of weeks for which contrarian returns are observed is $50 \%$.

$H_{1}$ : Proportion of weeks for which contrarian refurns are observed is greater than $50 \%$.

\section{Hypothesis 2:}

$H_{0}$ : Weekly annualized contrarian returns are zero.

$\mathrm{H}_{1}$ : Weekly annualized contrarian returns are greater then zero.

\section{Hypothesis 3:}

$\mathrm{H}_{0}$ : Proportion of weeks for which momentum returns are observed is $50 \%$.

$\mathrm{H}_{1}$ : Proportion of weeks for which momentum returns are observed is greater than $50 \%$.

\section{Hypothesis 4:}

$H_{0}$ : Weekly annualized momentum returns are zero.

$H_{1}$ : Weekly annualized momentum returns are greater then zero.

\section{Hypothesis Testing:}

Hypotheses have been tested for statistical significance using one tailed test of proportions and one tailed test means. Testing has been done to test significance at $5 \%$ significance level. The set of hypotheses listed evaluate the frequency of occurrence of contrarian and momentum profits and also the magnitude of contrarian and momentum profits. The hypotheses have 
been tested for all combinations of holdings periods 1-26 and formation period 1, 2, 4 and 8 weeks.

\section{Analysis of the Data}

\section{Profitability of Contrarian and Momentum Strategies:}

To study the profitability of momentum and contrarian strategies for various formations and holding periods, the student's $f$ distribution and $Z$ test have been used. T- Test has been used if the contrarian and momentum strategy yield positive return for higher number of weeks (null hypotheses 1 and 3). $Z$ test has been used to see if the contrarian and the momentum strategy lead to statistically significant positive returns (null hypotheses 2 and 4) i.e. if the overall return is positive or not.

We will first discuss the summarized results for the 8 year period of 19942001 after which detailed analysis and results for each year has been discussed.

\section{Summary results of the Contrarian Strategy}

\section{Formation period One Week}

For the formation period 1 -week returns are negative for all holding periods. But returns become more negative as holding period increases indicating that strategy becomes more and more ineffective for the greater holding periods when the formation period is one week. For $1,2,4,8,12,16,20$ and 26 week holding periods, less than $50 \%$ of the time returns are positive.

We don't find statistically significant evidence to reject the null hypotheses 1 and 2, hence the contrarian strategy doesn't work in this case.

\begin{tabular}{|l|l|c|c|c|c|c|c|c|c|}
\hline Proportion & t-value & -0.2632 & -0.2632 & -3.8421 & -6.3684 & -7.7368 & -7.3158 & -7.6316 & -7.6316 \\
Test & t-prob & NA & NA & NA & NA & NA & NA & NA & NA \\
& Significance & - & - & - & - & - & - & - & - \\
\multirow{2}{*}{ Returns } & WAR & $-12.04 \%$ & $-20.11 \%$ & $-35.17 \%$ & $-42.35 \%$ & $-36.73 \%$ & $-36.16 \%$ & $-37.40 \%$ & $-34.75 \%$ \\
Test & P-value & 0.811 & 0.9769 & 1 & 1 & 1 & 1 & 1 & 1 \\
& Significance & - & - & - & - & - & - & - & - \\
\hline
\end{tabular}




\section{Formation period Two Weeks}

For the formation period 2 week contrarian returns are positive for holding periods 1,2 and 4 weeks. But returns become negative as holding period increases, indicating that strategy becomes more and more ineffective for the greater holding periods. For 1, 2 and 4 weeks, more than $50 \%$ of the times positive returns are observed, but the number of weeks for which return is positive is not statistically significant. For $8,12,16,20$ and 26 weeks proportion is less than $50 \%$. It is important to note that although there is a trend that can be observed, but no statistically significant contrarian profits are seen for the formation period 2 weeks at the significant level of $5 \%$.

We don't find statistically significant evidence to reject the null hypotheses 1 and 2; hence the contrarian strategy doesn't work in this case.

\begin{tabular}{|l|l|c|c|c|c|c|c|c|c|}
\hline Proportion & t- value & 0.6326 & 0.6325 & 0.6325 & -0.9487 & -2.0028 & -2.2136 & -2.0028 & -1.4757 \\
Test & t-prob & 0.2637 & 0.3368 & 0.2637 & NA & NA & NA & NA & NA \\
& Significance & - & - & - & - & - & - & - & - \\
Returns & WAR & $11.93 \%$ & $10.80 \%$ & $1.82 \%$ & $-7.47 \%$ & $-10.64 \%$ & $-8.69 \%$ & $-10.70 \%$ & $-11.86 \%$ \\
Test & P-value & 0.1796 & 0.1181 & 0.4006 & 0.9341 & 0.9908 & 0.9796 & 0.9956 & 0.9986 \\
& Significance & - & - & - & - & - & - & - & - \\
\hline
\end{tabular}

\section{Formation period Four -Weeks}

For the formation period 4 week contrarian returns are positive for holding periods 1 and 2 weeks. But returns become negative as holding period increases indicating that strategy becomes more and more ineffective for the greater holding periods when the formation period is four weeks. For holding periods 1,2 and 4 weeks, positive returns are observed for more than $50 \%$ of times, but the proportion is statistically significant only for 2 week holding period. For $8,12,16,20$ and 26 weeks the proportion is less than $50 \%$.

We reject null hypothesis 1 for the formation period 4 weeks and the holding period 2 weeks. But we don't have sufficient evidence to reject the null hypothesis 2 . Hence even for 2 week holding period contrarian strategy cannot be said to be successful. 


\begin{tabular}{|l|l|c|c|c|c|c|c|c|c|}
\hline Proportion & t- value & 0.0526 & 0.0526 & 1.2015 & -2.4737 & -3.6893 & -3.8421 & -3.4211 & -4.4737 \\
Test & t-prob & 0.479 & 0.0121 & 0.1134 & NA & NA & NA & NA & NA \\
& Significance & - & $5 \%$ & - & - & - & - & - & - \\
Returns & WAR & $8.04 \%$ & $2.26 \%$ & $-8.81 \%$ & $-7.47 \%$ & $-10.64 \%$ & $-8.69 \%$ & $-10.70 \%$ & $-11.86 \%$ \\
Test & P-value & 0.1796 & 0.1181 & 0.4006 & 0.9341 & 0.9908 & 0.9796 & 0.9956 & 0.9986 \\
& Significance & - & - & - & - & - & - & - & - \\
\hline
\end{tabular}

\section{Formation period Eight-Weeks}

For the formation period 8 week returns are negative for all holdings periods. But returns become more negative as holding period increases indicating that strategy becomes more and more ineffective for the greater holding periods. For all holding periods, less than $50 \%$ of the time positive returns are observed.

We don't find statistically significant evidence to reject null hypotheses 1 and 2, hence the contrarian strategy doesn't work in this case.

\begin{tabular}{|l|l|c|c|c|c|c|c|c|c|}
\hline Proportion & t- value & -0.2632 & -0.2632 & -3.8421 & -6.3684 & -7.7368 & -7.3158 & -7.6316 & -7.6316 \\
Test & t-prob & NA & NA & NA & NA & NA & NA & NA & NA \\
& Significance & - & $5 \%$ & - & - & - & - & - & - \\
\multirow{2}{*}{ Returns } & WAR & $-12.04 \%$ & $-20.11 \%$ & $-35.17 \%$ & $-42.37 \%$ & $-36.73 \%$ & $-36.16 \%$ & $-37.40 \%$ & $-34.75 \%$ \\
Test & P-value & 0.811 & 0.9769 & 1 & 1 & 1 & 1 & 1 & 1 \\
& Significance & - & - & - & - & - & - & - & - \\
\hline
\end{tabular}

\section{Summary results of the Momentum Strategy}

\section{Formation period One-Week:}

When the formation period is 1 week, statistically significant momentum returns can be observed for the holding periods 20 and 26 weeks. For the

holding period 26 weeks, proportion test is significant at $5 \%$ significant level. Also momentum returns increase with the increase in holding period.

For the holding period 26 weeks we reject null hypotheses 3 and 4 , hence momentum strategy is successful for formation period 1 week and holding period 26 weeks. 
For the holding period 20 weeks we reject hypothesis, hence statistically significant momentum returns are observed.

\begin{tabular}{|l|l|c|c|c|c|c|c|c|c|}
\hline Proportion & t-value & -1.3158 & -1.3158 & -1.6316 & -1.6316 & 0.0526 & 0.3684 & 1.5263 & 1.8421 \\
Test & t-prob & NA & NA & NA & NA & 0.476 & 0.3564 & 0.0639 & 0.0331 \\
& Significance & - & $5 \%$ & - & - & - & - & - & $5 \%$ \\
Returns & WAR & $-10.82 \%$ & $-11.42 \%$ & $-3.92 \%$ & $3.01 \%$ & $7.31 \%$ & $6.24 \%$ & $7.89 \%$ & $8.22 \%$ \\
Test & P-value & 0.8173 & 0.9093 & 0.7233 & 0.2703 & 0.0532 & 0.0753 & 0.0333 & 0.0321 \\
& Significance & - & - & - & - & - & - & $5 \%$ & $5 \%$ \\
\hline
\end{tabular}

\section{Formation period Two Weeks:}

When the formation period is 2 weeks, statistically significant momentum returns can be observed for the holding periods 12, 16, 20 and 26 weeks.

For holding period 12,16 and 20 weeks, proportion test is significant at $5 \%$ significance level. Also momentum returns increase with the increase in holding period. For the holding period 12,16 and 20 weeks we reject null hypotheses 3 and 4 , hence momentum strategy is successful for the formation period 2 week and holding period 12, 16 and 20 weeks. For the holding period 26 weeks we reject hypotheses 4 , hence statistically significant momentum returns are observed.

\begin{tabular}{|l|l|c|c|c|c|c|c|c|c|}
\hline Proportion & t- value & -0.6325 & -0.6325 & -0.6325 & 0.9487 & 2.0028 & 2.2136 & 2.0028 & 1.4757 \\
Test & t-prob & NA & NA & NA & 0.1717 & 0.023 & 0.0137 & 0.023 & 0.0704 \\
& Significance & - & - & - & - & $5 \%$ & $5 \%$ & $5 \%-$ & \\
Returns & WAR & $11.93 \%$ & $-10.80 \%$ & $-1.82 \%$ & $7.47 \%$ & $10.64 \%$ & $8.69 \%$ & $10.70 \%$ & $11.86 \%$ \\
Test & P-value & 0.8204 & 0.8819 & 0.5994 & 0.0659 & 0.0092 & 0.0204 & 0.0044 & 0.0011 \\
& Significance & - & - & - & - & $1 \%$ & $5 \%$ & $1 \%$ & $1 \%$ \\
\hline
\end{tabular}

\section{Formation period Four -Weeks:}

When the formation period is 4 weeks, statistically significant momentum returns can be observed for the holding periods $8,12,20$ and 26 weeks.

For the holding period $2,4,8,12,16,20$ and 26 weeks. For holding period $2,4,8,12,16$ and 26 weeks, proportion test is significant at $5 \%$ significance level. Also momentum returns increase with the increase in holding period 
in general, but in this case highest momentum returns are observed for 8 week holding period. This can be treated as an aberration fro the trend.

For the holding period $2,4,8,12,16$ and 26 weeks we reject null hypotheses 3 and 4 , hence momentum strategy is successful for the formation period 8 week and holding period 2,4,8,12,16, 20 and 26 weeks.

\begin{tabular}{|l|l|c|c|c|c|c|c|c|c|}
\hline Proportion & t- value & -0.0526 & -0.0526 & -1.2105 & 1.7368 & 2.2036 & 3.1053 & 2.6842 & 3.7368 \\
Test & t-prob & NA & NA & NA & 0.0416 & 0.0137 & 0.001 & 0.0038 & 0.0001 \\
& Significance & - & - & - & $5 \%$ & $5 \%$ & $1 \%$ & $1 \%$ & $1 \%$ \\
Returns & WAR & $-8.04 \%$ & $-2.26 \%$ & $8.81 \%$ & $24.21 \%$ & $21.42 \%$ & $20.29 \%$ & $21.71 \%$ & $19.54 \%$ \\
Test & P-value & 0.7285 & 0.595 & 0.1128 & 0 & 0 & 0 & 0 & 0 \\
& Significance & - & - & - & $1 \%$ & $1 \%$ & $1 \%$ & $1 \%$ & $1 \%$ \\
\hline
\end{tabular}

\section{Proportion Test for the Contrarian Strategy}

To prove the hypothesis $t$ test is used on the results obtained for different formation periods and holding period. Following hypotheses have been stested

$H_{0}$ : Proportion of weeks for which contrarian returns are observed is $50 \%$.

$H_{1}$ : Proportion of weeks for which contrarian returns are observed is greater than $50 \%$ 


\begin{tabular}{|c|c|c|c|c|c|c|c|c|c|}
\hline \multirow{2}{*}{ 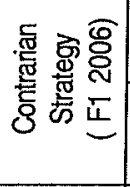 } & 号 & ' & . & ' & ' & ' & . & . & \\
\hline & 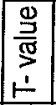 & $\begin{array}{l}\text { 㞻 } \\
\text { 吊 } \\
0\end{array}$ & ్ָ̃ & 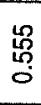 & 0 & 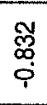 & 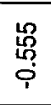 & 响 & 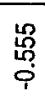 \\
\hline \multirow{2}{*}{ 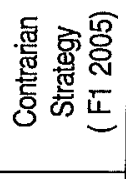 } & (잉 & ' & ' & ถัำ & ¿̊ำ & ' & ' & ' & ' \\
\hline & \begin{tabular}{|l|}
$\frac{0}{3}$ \\
$\frac{3}{7}$ \\
1 \\
5
\end{tabular} & 0 & $\begin{array}{l}\text { 㟔 } \\
\text { 号 } \\
\end{array}$ & \begin{tabular}{l}
$\stackrel{\$}{0}$ \\
\hdashline \\
\end{tabular} & 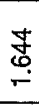 & 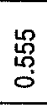 & $\begin{array}{l}\text { 今 } \\
\text { }\end{array}$ & $\begin{array}{l}\widetilde{N} \\
\infty \\
0 \\
0 \\
0\end{array}$ & 太్ \\
\hline \multirow{2}{*}{ 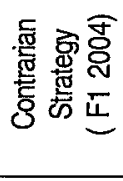 } & 응 & ' & ' & ' & ' & ' & ' & ' & \\
\hline & 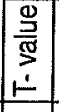 & $\frac{\hat{m}}{\dot{0}}$ & $\begin{array}{l}0 \\
00 \\
0 \\
\end{array}$ & $\begin{array}{l}\infty \\
\infty \\
0 \\
1\end{array}$ & 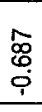 & $\begin{array}{l}10 \\
80 \\
0 \\
\end{array}$ & $\begin{array}{l}0 \\
0 \\
0 \\
\\
\end{array}$ & $\underset{\widehat{\gamma}}{\mathrm{\gamma}}$ & 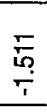 \\
\hline \multirow{2}{*}{ 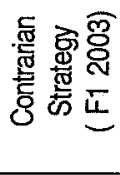 } & 媭 & ' & ' & ' & ' & ' & ' & ' & ' \\
\hline & \begin{tabular}{|l|}
$\frac{9}{3}$ \\
$\frac{2}{3}$ \\
\\
\end{tabular} & 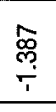 & 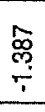 & E़ & $\begin{array}{l}\text { Aิ } \\
\text { ฺ } \\
\end{array}$ & \begin{tabular}{l}
\multirow{8}{0}{} \\
\\
\end{tabular} & 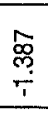 & $\begin{array}{l}\bar{*} \\
\bar{T}\end{array}$ & 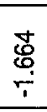 \\
\hline \multirow{2}{*}{ 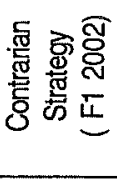 } & (5) & . & . & ' & ' & ' & ' & . & ' \\
\hline & 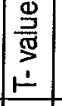 & $\begin{array}{l}\text { 总 } \\
\text { 员 } \\
0\end{array}$ & $\begin{array}{l}\widetilde{\widetilde{J}} \\
\infty \\
0 \\
0\end{array}$ & $\begin{array}{l}10 \\
\text { గn } \\
0 \\
0\end{array}$ & 0 & $\begin{array}{l}\text { N్ } \\
\infty \\
0 \\
\end{array}$ & 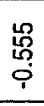 & $\begin{array}{c}\text { og } \\
\stackrel{9}{+} \\
\end{array}$ & $\begin{array}{l}\text { 员 } \\
\text { م̣ } \\
\end{array}$ \\
\hline \multirow{2}{*}{ 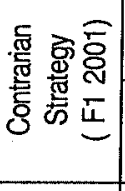 } & का & ' & . & i̊ & 운 & ' & ' & ' & ' \\
\hline & 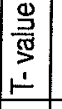 & $\hat{o}$ & $\hat{o}$ & 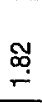 & 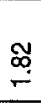 & $\tilde{O}$ & $\begin{array}{l}\infty \\
0 \\
0\end{array}$ & $\stackrel{+}{\circ}$ & $\begin{array}{l}\text { o } \\
\stackrel{9}{\phi}\end{array}$ \\
\hline \multirow{2}{*}{ 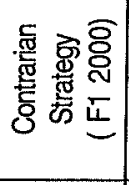 } & 品 & ㅇํ & i̊ & . & & ' & ' & ' & ' \\
\hline & 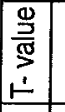 & $\stackrel{+}{+}$ & $\begin{array}{l}\mathbb{8} \\
\text { Nu } \\
\text { Ni }\end{array}$ & 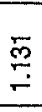 & $\begin{array}{l}\text { 悉 } \\
0 \\
0\end{array}$ & 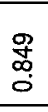 & $\begin{array}{l}\text { go } \\
\infty \\
0 \\
0\end{array}$ & 0 & $\begin{array}{l}\mathscr{8} \\
0 \\
0 \\
\end{array}$ \\
\hline \multirow{2}{*}{ 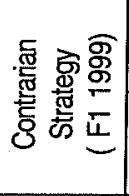 } & 융 & $\begin{array}{l}\stackrel{\circ}{\circ} \\
\text { ớ } \\
\text { Oे }\end{array}$ & 。̊ㅇํ & ' & ' & ' & ' & ' & ' \\
\hline & 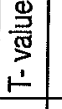 & $\bar{c}$ & 蒙 & $\begin{array}{l}\text { Yे } \\
\text { Q }\end{array}$ & $\begin{array}{l}\stackrel{8}{\circ} \\
\stackrel{\circ}{\circ}\end{array}$ & $\begin{array}{l}\text { 号 } \\
\text { 。 }\end{array}$ & $\stackrel{ \pm}{\circ}$ & 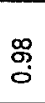 & $\frac{ \pm}{\circ}$ \\
\hline 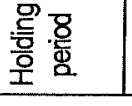 & & - & $\sim$ & $\forall$ & $\infty$ & $\cong$ & 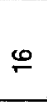 & ని & $\stackrel{\mathscr{N}}{ }$ \\
\hline
\end{tabular}


- In the year 1999 the contrarian strategy is profitable for greater number of weeks for all but holding periods of 4,7,17 and 25 weeks. But only the contrarian profit for holding periods 1 and 2 weeks is statistically significant for a higher number of weeks.

- In the year 2000 Contrarian Strategy is profitable for greater number of weeks for all but holding periods of 24,25 and 26 weeks. But only the contrarian profit for holding periods 1,2 and 3 weeks is statistically significant for a higher number of weeks.

- In the year 2001 Contrarian Strategy is profitable for greater number of weeks for all but holding periods of $1,2,4,5,6,7,8$ and 9 weeks. But only the contrarian profit for holding periods 6 and 7 weeks is statistically significant for a higher number of weeks.

- In the year 2002 Contrarian Strategy is profitable for greater number of weeks holding periods of 6 and 7 weeks and that too is not statistically significant.

- In the year 2003 Contrarian Strategy is profitable for greater number of weeks holding periods of 1 and 2 weeks and that too is not statistically significant.

- In the year 2004 Contrarian Strategy is profitable for greater number of weeks for all but holding periods of 10,16 and 25 weeks. But only the contrarian profit for holding periods 4 and 8 weeks is statistically significant for a higher number of weeks.

- In the year 2005 Contrarian Strategy is profitable for greater number of weeks for all but holding periods of 12,15,16 and 20-26 weeks. But only the contrarian profit for holding periods 1,2, 4 and 7 weeks is statistically significant for a higher number of weeks. 


\begin{tabular}{|c|c|c|c|c|c|c|c|c|c|}
\hline \multirow{2}{*}{ 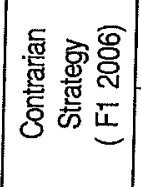 } & 号 & & . & . & & ' & ' & \multicolumn{2}{|l|}{ • } \\
\hline & 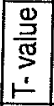 & $\begin{array}{l}\mathscr{N} \\
\infty \\
0\end{array}$ & 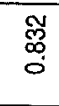 & 总 & 0 & 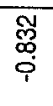 & 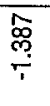 & 움 & 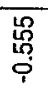 \\
\hline \multirow{2}{*}{ 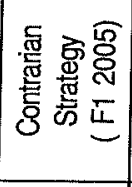 } & 曲 & & ' & ' & ' & ' & ' & ' & ' \\
\hline & \begin{tabular}{|l|}
$\frac{D}{3}$ \\
$\frac{9}{3}$ \\
1 \\
\\
\end{tabular} & 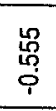 & $\begin{array}{l}\text { Eิ } \\
\text { Ș }\end{array}$ & 0 & 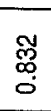 & 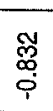 & 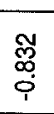 & $\begin{array}{l}\mathscr{N} \\
\infty \\
0 \\
i\end{array}$ & 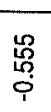 \\
\hline \multirow{2}{*}{ 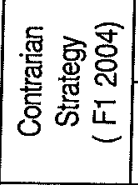 } & 品 & ' & ' & ' & · & ' & ' & ' & ' \\
\hline & 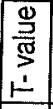 & 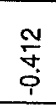 & $\underset{T}{\frac{\Gamma}{6}}$ & $\begin{array}{l}0 \\
\text { ণั } \\
\end{array}$ & 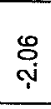 & $\stackrel{\stackrel{0}{5}}{\frac{1}{7}}$ & 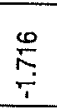 & 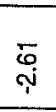 & $\begin{array}{l}0 \\
\text { ஸ̦ } \\
\end{array}$ \\
\hline \multirow{2}{*}{ 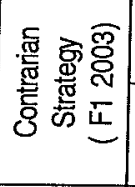 } & 잉 & 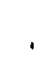 & · & ' & ' & ' & ' & . & \\
\hline & 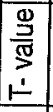 & $\begin{array}{l}g \\
\\
\\
\end{array}$ & $\begin{array}{l}\text { 岇 } \\
\text { مo } \\
\stackrel{i}{8}\end{array}$ & 今̂ & $\frac{\bar{\sigma}}{+}$ & $\frac{\bar{\sigma}}{\sigma}$ & 芯 & 疍 & 翻 \\
\hline \multirow{2}{*}{ 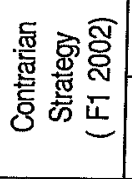 } & $\frac{\mathscr{O}}{\mathrm{S}}$ & . & . & . & . & ' & . & . & . \\
\hline & 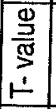 & $\begin{array}{l}\stackrel{\leftrightarrow}{0} \\
\stackrel{\circ}{\circ}\end{array}$ & $\begin{array}{l}\text { 虽 } \\
\text { ํㅜ }\end{array}$ & 0 & $\begin{array}{l}\stackrel{\leftrightarrow}{0} \\
\stackrel{0}{0} \\
0\end{array}$ & ิㅗํ & 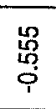 & Ẹ̃ & $\frac{\text { g }}{\div !}$ \\
\hline \multirow{2}{*}{ 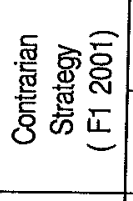 } & 号 & ' & ' & ' & ' & ' & . & . & $\cdot$ \\
\hline & 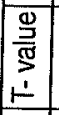 & 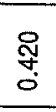 & $\stackrel{R}{\stackrel{R}{\circ}}$ & $\begin{array}{l}\stackrel{8}{8} \\
\stackrel{-}{~} \\
\end{array}$ & $\begin{array}{l}\stackrel{9}{4} \\
i \\
i\end{array}$ & $\begin{array}{l}\text { 员 } \\
0 \\
0\end{array}$ & 兽 & 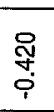 & $\stackrel{8}{\stackrel{8}{0}}$ \\
\hline \multirow{2}{*}{ 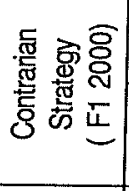 } & 嗢 & & ' & ' & ' & ' & ' & ' & ' \\
\hline & 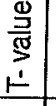 & 怘 & $\underset{\frac{m}{\sigma}}{\check{r}}$ & $\underset{m}{m}$ & $\begin{array}{l}\mathscr{心} \\
\stackrel{\circ}{\circ} \\
0\end{array}$ & 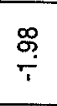 & 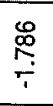 & $\begin{array}{l}\text { 守 } \\
\stackrel{0}{0}\end{array}$ & $\begin{array}{l}\stackrel{9}{0} \\
\vdots \\
0\end{array}$ \\
\hline \multirow{2}{*}{ 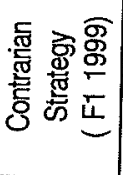 } & 品 & 亡̊ & ஃ̊ํ & i̊ & · & 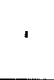 & . & ' & . \\
\hline & 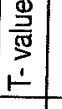 & $\underset{\substack{f \\
\dot{m}}}{E}$ & 芯 & 总 & $\frac{\bar{m}}{\frac{1}{1}}$ & $\begin{array}{l}\bar{\sigma} \\
\\
\end{array}$ & 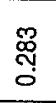 & 0 & $\begin{array}{l}g \\
\$ \\
0 \\
0\end{array}$ \\
\hline $\begin{array}{l}\text { 믕 } \\
\text { 응 } \\
\text { 옴 }\end{array}$ & & $r$ & $\sim$ & 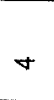 & $\infty$ & $\cong$ & $\stackrel{0}{ }$ & 오 & $\stackrel{\sim}{\circ}$ \\
\hline
\end{tabular}


- In the year 1999 Contrarian Strategy is profitable for greater number of weeks for all but holding periods of 7-15 week. But only the contrarian profit for holding periods $1,2,3$ and 4 weeks is statistically significant for a higher number of weeks.

- In the year 2000 Contrarian Strategy is profitable for greater number of weeks for all but holding periods of 5 and 14-18 weeks. But it is not statistically significant.

- In the year 2001 Contrarian Strategy is profitable for greater number of weeks for all but holding periods of 11,12 and 20-24 weeks. But only the contrarian profit for holding periods 3 and 5 weeks is statistically significant for a higher number of weeks.

- In the year 2002 Contrarian Strategy is profitable for greater number of weeks for all but holding periods of 3-7,9,17 and 18 week. But only the contrarian profit for holding periods 3 and 5 weeks is statistically significant for a higher number of weeks.

- In the year 2003 Contrarian Strategy is profitable for greater number of weeks for holding periods of 5 and 6 weeks and that too is not statistically significant.

- In the year 2004 Contrarian Strategy is profitable for greater number of weeks only for holding period of 5 weeks and the result is not statistically significant.

- In the year 2005 Contrarian Strategy is profitable for greater number of weeks for holding periods of 5 and $7-9$ weeks and that too is not statistically significant.

- In the year 2006 Contrarian Strategy is profitable for greater number of weeks for holding periods of $7-7$ and that too is not statistically significant. 


\begin{tabular}{|c|c|c|c|c|c|c|c|c|c|}
\hline \multirow{2}{*}{ 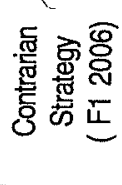 } & का & ڤั & i̊ & ' & & & & & \\
\hline & 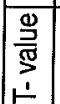 & 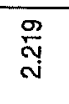 & 产 & 욤 & 商 & 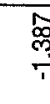 & 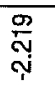 & $\stackrel{\bar{g}}{\stackrel{F}{*}}$ & \\
\hline \multirow{2}{*}{ 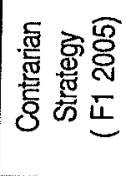 } & क & & i & ' & & . & '. & & \\
\hline & $\mid$ & 总 & 令 & $\begin{array}{l}\text { 总 } \\
\text { 虽 }\end{array}$ & 。 & $\begin{array}{l}\text { A } \\
\stackrel{9}{S}\end{array}$ & 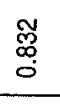 & $\begin{array}{l}\text { 邑 } \\
\text { 虽 }\end{array}$ & \\
\hline \multirow{2}{*}{ 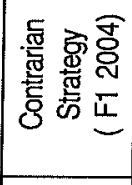 } & 0 & & . & & . & . & ' & ' & \\
\hline & $\mid$ & 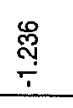 & $\begin{array}{l}\text { \%o } \\
\text { o. } \\
\end{array}$ & 器 & $\begin{array}{c}\text { 葛 } \\
\text { 字 }\end{array}$ & $\begin{array}{l}\text { ă } \\
a \\
a\end{array}$ & $\frac{g}{8}$ & 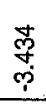 & \\
\hline \multirow{2}{*}{ 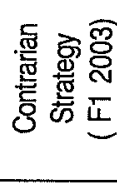 } & (i) & . & $\stackrel{\circ}{\circ}$ & & . & . & . & ' & \\
\hline & $\mid$ & $\begin{array}{c}\text { Si } \\
\text { S }\end{array}$ & 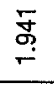 & 。 & 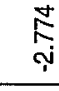 & 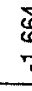 & ঙ্ষ & $\begin{array}{l}\bar{g} \\
\text {; } \\
\end{array}$ & \\
\hline \multirow{2}{*}{ 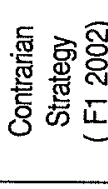 } & $\mid$ & $\cdot$ & ' & ڤ̊ & ' & & ' & ' & \\
\hline & 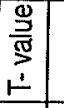 & $\begin{array}{l}\text { 兽 } \\
\text { 号 }\end{array}$ & 芯 & 悤 & 今్ & $\begin{array}{c}\stackrel{0}{\alpha} \\
c \\
c\end{array}$ & 芯 & 然 & $\frac{8}{7}$ \\
\hline \multirow{2}{*}{ 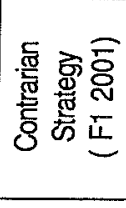 } & क & & 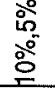 & 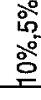 & & & . & & . \\
\hline & $\mid$ & 萨 & 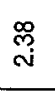 & $\stackrel{\varpi}{-}$ & $\stackrel{\circ}{\circ}$ & $\stackrel{\square}{\square}$ & $\hat{o}$ & Ұ̛ & 壱 \\
\hline \multirow{2}{*}{ 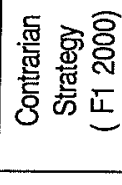 } & in & & $\cdot$ & ' & & & $\cdot$ & & ' \\
\hline & 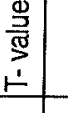 & 0 & 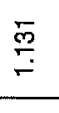 & 0 & 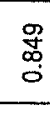 & $\begin{array}{c}\sigma \\
\text { o } \\
c \\
\\
\end{array}$ & 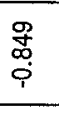 & 0 & 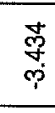 \\
\hline \multirow{2}{*}{ 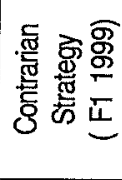 } & के & ' & . & & & & & . & . \\
\hline & 离 & $\begin{array}{r}\Delta \\
\end{array}$ & İ & $\begin{array}{l}\infty \\
\stackrel{8}{0} \\
\stackrel{0}{0}\end{array}$ & 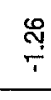 & 7 & 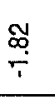 & $\begin{array}{l}\infty \\
0 \\
i \\
\end{array}$ & 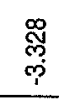 \\
\hline 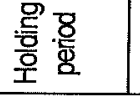 & & - & N & $\checkmark$ & ${ }^{\infty}$ & ร & $\stackrel{\circ}{\circ}$ & i & $\stackrel{\infty}{\sim}$ \\
\hline
\end{tabular}


- In the year 1999 Contrarian strategy is profitable for greater number of weeks only for holding periods of $1,2,3$ and 25 weeks and that too it is not statistically significant.

- In the year 2000 Contrarian Strategy is profitable for greater number of weeks for holding periods of 1 and 18-26 weeks. It is statistically significant only for 26 week holding period.

- In the year 2001 Contrarian Strategy is profitable for greater number of weeks for holding periods of 1-5 weeks. But only the contrarian profit for holding periods 2-4 weeks is statistically significant for a higher number of weeks.

- In the year 2002, 2003 and 2004 Contrarian strategy is not profitable for greater number of weeks for any holding period.

- In the year 2005 Contrarian Strategy is profitable for greater number of weeks for holding periods of 1 week and is statistically significant.

- For the year 2006 Contrarian strategy is profitable for greater number of weeks only for holding periods of 1-4 weeks and is statistically significant for 1 and 4 weeks.

\section{Mean test for the Contrarian Strategy}

To prove the hypothesis $Z$ test is used on the results obtained for different formation periods and holding period. Following hypotheses have been tested:

$H_{0}$ : Weekly annualized contrarian returns are zero

$\mathrm{H}_{1}$ : Weekly annualized contrarian returns are greater than zero 


\begin{tabular}{|c|c|c|c|c|c|c|c|c|c|}
\hline \multirow{2}{*}{ 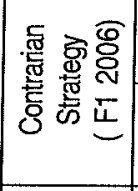 } & 品 & ' & . & ' & ' & ' & ' & ' & . \\
\hline & 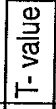 & $\begin{array}{l}10 \\
0 \\
0 \\
0 \\
0\end{array}$ & $\begin{array}{l}\text { N్ } \\
0 \\
0 \\
0\end{array}$ & 寜 & 용 & 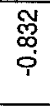 & 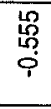 & 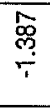 & 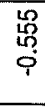 \\
\hline \multirow{2}{*}{ 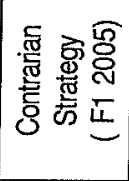 } & (ू) & ' & ' & $\stackrel{\circ}{\circ}$ & $\stackrel{\circ}{\circ}$ & ' & ' & $\cdot$ & \\
\hline & 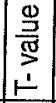 & $\begin{array}{l}8 \\
0 \\
0\end{array}$ & 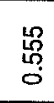 & 芯 & 某 & $\begin{array}{l}\text { 虽 } \\
\text { 号 }\end{array}$ & $\begin{array}{l}\text { N̦ } \\
i ̣\end{array}$ & $\begin{array}{l}\underset{N}{0} \\
\substack{0 \\
0}\end{array}$ & $\begin{array}{l}\text { E } \\
\text { Sִ }\end{array}$ \\
\hline \multirow{2}{*}{ 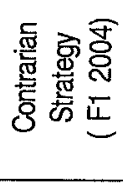 } & क & ' & ' & . & ' & ' & ' & ' & ' \\
\hline & $\begin{array}{c}\frac{0}{3} \\
\frac{3}{3} \\
1 \\
\end{array}$ & $\stackrel{\substack{0 \\
0}}{0}$ & $\begin{array}{l}\widehat{0} \\
\text { o } \\
\dot{0}\end{array}$ & $\begin{array}{l}\text { s. } \\
0 \\
0 \\
\end{array}$ & $\begin{array}{l}\text { s. } \\
0 \\
0 \\
\end{array}$ & 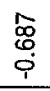 & $\begin{array}{l}0 \\
0 \\
0 \\
\end{array}$ & $\begin{array}{l}\text { 응 } \\
\text { ํ. } \\
\end{array}$ & $\underset{\overline{i n}}{\bar{T}}$ \\
\hline \multirow{2}{*}{ 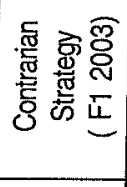 } & $\frac{\pi}{\infty}$ & ' & ' & ' & ' & · & ' & ' & . \\
\hline & \begin{tabular}{|l|}
$\frac{0}{3}$ \\
$\frac{9}{3}$ \\
1 \\
1
\end{tabular} & 总 & $\begin{array}{l}\infty \\
\text { po } \\
\end{array}$ & 太ي̣ & $\begin{array}{l}E \\
\text { Ș } \\
\end{array}$ & \begin{tabular}{l}
$\stackrel{+}{8}$ \\
\hdashline \\
\end{tabular} & 怘 & $\frac{\bar{\sigma}}{\sigma}$ & 志 \\
\hline \multirow{2}{*}{ 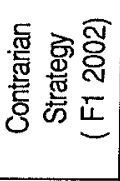 } & 응 & ' & ' & ' & ' & ' & ' & ' & . \\
\hline & \begin{tabular}{|l|}
$\frac{0}{3}$ \\
$\frac{3}{3}$ \\
1 \\
1 \\
\end{tabular} & 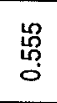 & $\begin{array}{l}\widetilde{N} \\
\infty \\
0 \\
0\end{array}$ & 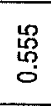 & $\begin{array}{l}8 \\
0 \\
0\end{array}$ & $\begin{array}{l}\widetilde{N} \\
\substack{0 \\
i}\end{array}$ & 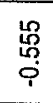 & $\begin{array}{c}\widehat{\infty} \\
\stackrel{\oplus}{+}\end{array}$ & 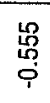 \\
\hline \multirow{2}{*}{ 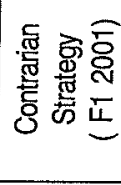 } & क & ' & . & 요 & 웅 & ' & ' & ' & ' \\
\hline & \begin{tabular}{|l|}
$\frac{9}{2}$ \\
$\frac{2}{3}$ \\
1 \\
1 \\
\end{tabular} & $\frac{8}{\stackrel{8}{0}}$ & $\underset{\stackrel{8}{\circ}}{\stackrel{8}{\circ}}$ & $\underset{\infty}{\stackrel{\$}{-~}}$ & ్ָ & $\begin{array}{l}8 \\
\stackrel{8}{0}\end{array}$ & $\begin{array}{l}\stackrel{8}{8} \\
\stackrel{8}{0} \\
0\end{array}$ & $\frac{g}{\circ}$ & 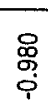 \\
\hline \multirow{2}{*}{ 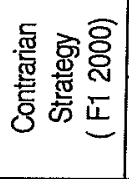 } & (응 & ஸे & $\stackrel{\circ}{\circ}$ & ' & ' & ' & ' & 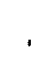 & ' \\
\hline & 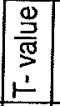 & $\underset{⿱}{ \pm}$ & 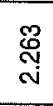 & $\stackrel{5}{\circ}$ & $\begin{array}{l}\text { ơ } \\
\text { ’ }\end{array}$ & 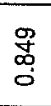 & $\begin{array}{l}\text { g } \\
\text { o } \\
0\end{array}$ & $\begin{array}{l}8 \\
8 \\
0\end{array}$ & $\begin{array}{l}\mathscr{8} \\
\stackrel{8}{10} \\
0\end{array}$ \\
\hline \multirow{2}{*}{ 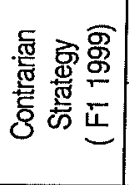 } & 号 & 웅 & ㅇํㅇ & ' & ' & ' & ' & ' & . \\
\hline & 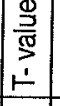 & $\frac{8}{\circ}$ & 웅 & \begin{tabular}{l} 
\$্ \\
\hdashline \\
\end{tabular} & $\begin{array}{l}8 \\
8 \\
0 \\
0 \\
\end{array}$ & $\begin{array}{l}8 \\
8 \\
\circ \\
0\end{array}$ & $\frac{9}{\frac{9}{0}}$ & $\begin{array}{l}\mathscr{O} \\
\stackrel{0}{0} \\
0 \\
\end{array}$ & $\frac{8}{\square}$ \\
\hline $\begin{array}{l}\text { 옿 } 8 \\
\text { 흥용 } \\
\end{array}$ & & - & $\sim$ & $\nabla$ & $\infty$ & 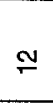 & $\mathscr{O}$ & ని & $\mathscr{N}$ \\
\hline
\end{tabular}


- In the year 1999 contrarian strategy yields positive returns for all holding periods. The result is statistically significant for holding period of 1,2 and 3 weeks.

- In the year 2000 contrarian strategy yields positive returns for all but holding periods of 16,17 and 19 weeks. The result is statistically significant for holding period of $1,2,3$ and 4 weeks.

- In the year 2001 contrarian strategy yields positive returns for all but holding periods 18.26 weeks. The result is statistically significant for holding period of 6 and 7 weeks.

- In the year 2002 contrarian strategy yields negative returns for all but holding periods.

- In the year 2003 contrarian strategy yields negative returns for all but holding periods.

- In the year 2004 contrarian strategy yields negative returns for all but holding periods.

- In the year 2005 contrarian strategy yields positive returns for all but holding periods. But the result is not statistically significant for any holding period.

- In the year 2006 contrarian strategy yields positive returns for all holding periods of $15,16,17,22$ and 23 weeks. But the result is statistically significant only for holding period of 1,2 and 4 weeks. 


\begin{tabular}{|c|c|c|c|c|c|c|c|c|c|}
\hline \multirow{2}{*}{ 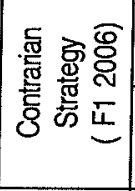 } & क & ' & & ' & ' & ' & . & ' & ' \\
\hline & 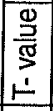 & $\begin{array}{c}\widetilde{\mathscr{N}} \\
\substack{0 \\
0}\end{array}$ & 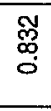 & 욤 & 8 & 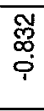 & 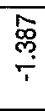 & 웅 & 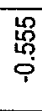 \\
\hline \multirow{2}{*}{ 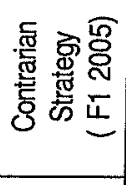 } & कू & ' & ' & ' & ' & ' & ' & ' & . \\
\hline & \begin{tabular}{|l|} 
\\
3 \\
3 \\
\end{tabular} & $\begin{array}{l}\text { 㟔 } \\
\text { i }\end{array}$ & 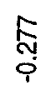 & ষ্ণ & $\begin{array}{l}\text { N్ } \\
\text { ơ } \\
\text { o }\end{array}$ & 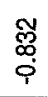 & 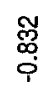 & $\begin{array}{l}\widetilde{N} \\
\stackrel{0}{0} \\
\stackrel{9}{i}\end{array}$ & 萼 \\
\hline \multirow{2}{*}{ 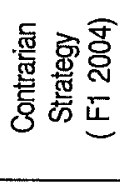 } & 品 & ' & ' & ' & . & ' & ' & ' & \\
\hline & 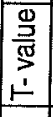 & $\begin{array}{l}\text { No } \\
\dot{+} \\
i \\
\end{array}$ & $\frac{5}{5}$ & $\begin{array}{l}8 \\
\stackrel{8}{ } \\
\text { ฺ̣ }\end{array}$ & $\begin{array}{l}8 \\
\varnothing \\
\text { ชุ }\end{array}$ & $\stackrel{20}{\check{\Gamma}}$ & $\frac{0}{1}$ & 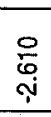 & $\begin{array}{l}8 \\
\varnothing \\
\\
\end{array}$ \\
\hline \multirow{2}{*}{ 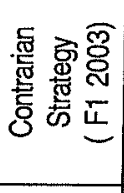 } & 융 & ' & ' & ' & ' & ' & ' & $\cdot$ & ' \\
\hline & 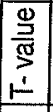 & \begin{tabular}{r} 
P \\
\hdashline \\
\hdashline \\
\end{tabular} & 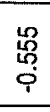 & 今̀ & $\frac{\bar{\sigma}}{7}$ & $\frac{\bar{\sigma}}{\sigma}$ & \begin{tabular}{l}
\multirow{0}{0}{} \\
$\vdots$ \\
\end{tabular} & 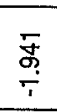 & 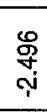 \\
\hline \multirow{2}{*}{ 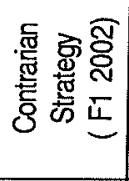 } & 品 & ' & 1 & ' & ' & ' & ' & ' & ' \\
\hline & 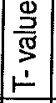 & 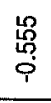 & $\begin{array}{l}\text { 䓪 } \\
\stackrel{0}{0} \\
\end{array}$ & 8. & 总 & 今̦ & 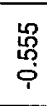 & ్ㅗ & $\frac{g}{\frac{0}{1}}$ \\
\hline \multirow{2}{*}{ 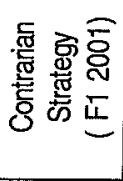 } & 응 & ' & ' & · & ' & . & ' & . & . \\
\hline & 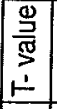 & ঙ্ণ & $\begin{array}{l}8 \\
\stackrel{8}{0} \\
\end{array}$ & 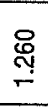 & $\begin{array}{l}\text { ণ্} \\
\text { ণ }\end{array}$ & 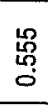 & $\begin{array}{l}8 \\
\stackrel{8}{\circ} \\
\end{array}$ & $\begin{array}{l}\text { ษ্ } \\
\text { î }\end{array}$ & $\begin{array}{l}8 \\
0 \\
0\end{array}$ \\
\hline \multirow{2}{*}{ 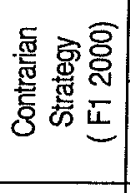 } & $\frac{D}{5}$ & & ' & ' & 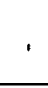 & ' & ' & ' & . \\
\hline & 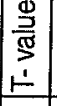 & 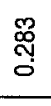 & $\stackrel{\bar{m}}{\sigma}$ & $\stackrel{\bar{m}}{\stackrel{5}{\circ}}$ & $\begin{array}{l}\stackrel{8}{0} \\
\stackrel{\circ}{\circ} \\
0\end{array}$ & 吕 & \begin{tabular}{l}
$\mathscr{8}$ \\
$\stackrel{0}{0}$ \\
\hdashline \\
\end{tabular} & 㤐 & $\begin{array}{l}\text { O } \\
\text { o } \\
0\end{array}$ \\
\hline \multirow{2}{*}{ 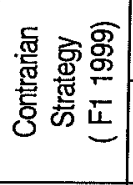 } & 응 & ㅇํㅇ & ㅇํㅇ & iั่ & ' & 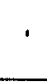 & ' & ' & ' \\
\hline & 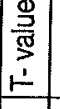 & 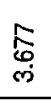 & $\begin{array}{l}\text { 怘 } \\
\text { స్ }\end{array}$ & 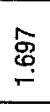 & $\frac{\bar{m}}{\bar{T}}$ & $\begin{array}{c}\frac{7}{6} \\
\\
\end{array}$ & $\begin{array}{l}\mathscr{8} \\
\stackrel{3}{0} \\
0\end{array}$ & 응 & $\begin{array}{l}\text { 呆 } \\
\text { ○. } \\
0\end{array}$ \\
\hline $\begin{array}{l}\text { 읗 } 8 \\
\text { 응 } \\
\text { 옹 }\end{array}$ & & - & $N$ & + & $\infty$ & $\dddot{W}$ & 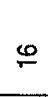 & ని & $\mathscr{N}$ \\
\hline
\end{tabular}


- In the year 1999 Contrarian Strategy yields positive returns for all holding period. But the result is statistically significant only for the holding period of 1 and 2 weeks.

- In the year 2000 Contrarian Strategy yields positive returns for holding periods of $1-4,7-9,11,21$ and 26 weeks. But the result is not statistically significant for any holding period.

- In the year 2001 Contrarian Strategy yields positive returns for holding periods of $1-16$ weeks. But the result is statistically significant only for the holding period of 3-9 weeks.

- In the year 2002 Contrarian Strategy yields positive returns for holding periods of 3-20 weeks. The result is statistically significant only for the holding period of 5-7 weeks.

- In the year 2003 Contrarian Strategy yields negative returns for all holding period.

- In the year 2004 Contrarian Strategy yields negative returns for all holding period.

- In the year 2005 Contrarian Strategy yields positive returns for holding periods of 1-8 and 14-22 weeks. But the result is not statistically significant for any holding period.

- In the year 2006 Contrarian Strategy yields positive returns for holding periods of 1-11 weeks. The result is statistically significant only for the holding period of I week. 


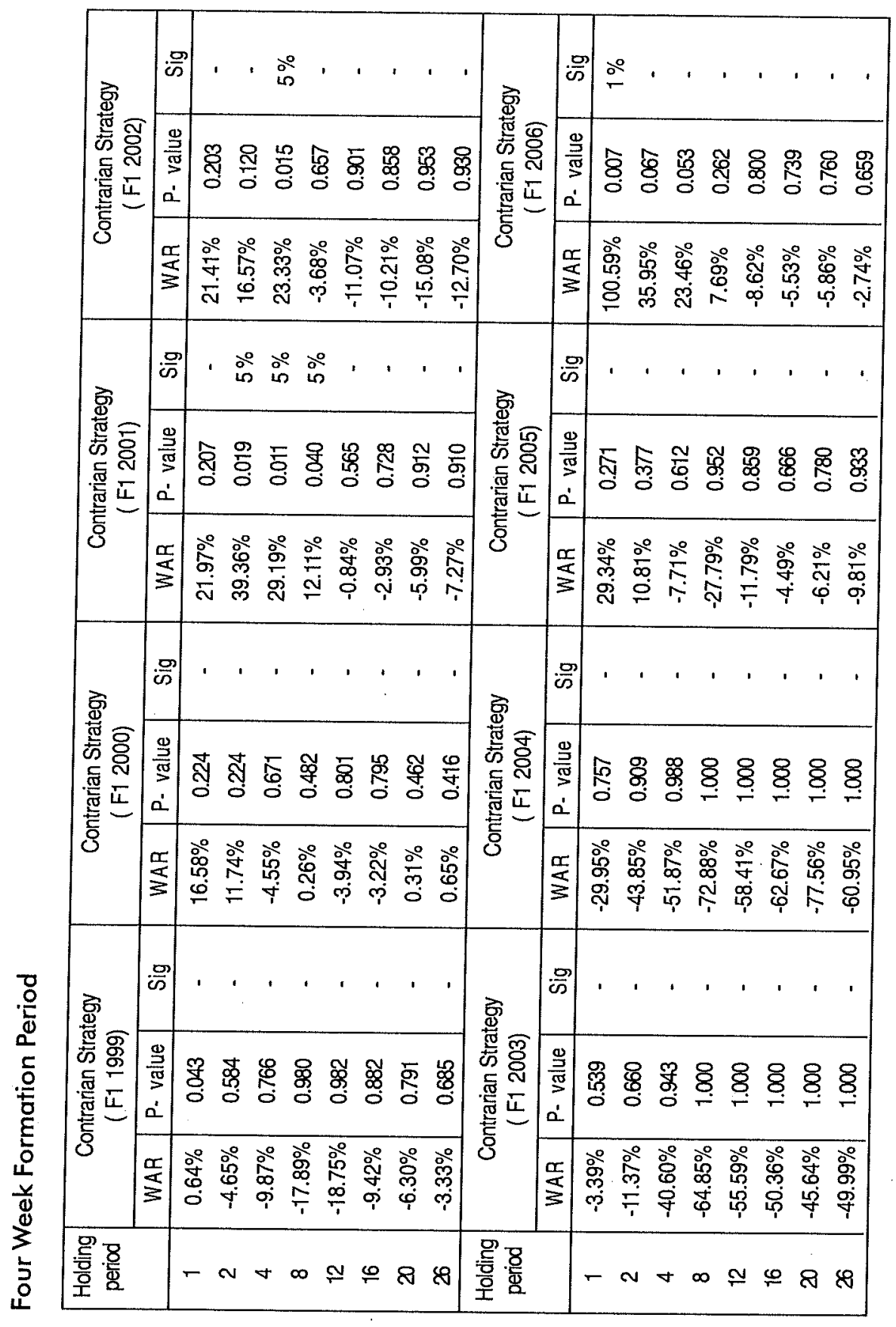


- In the year 1999 Contrarian Strategy yields positive results only for holding period of 1 week and it is not statistically significant.

- In the year 2000 Contrarian strategy yields positive returns for the holding periods of $1-3,8,19,20,24,25$ and 26 weeks. But the result is not statistically significant for any holding period.

- In the year 2001 Contrarian strategy yields positive returns for the holding periods of $1-10,13$ and 14 weeks. The result is statistically significant for holding period 2-8 weeks.

- In the year 2002 Contrarian strategy yields positive returns for the holding periods of $1-7$ weeks. The result is statistically significant for holding period 3 and 4 weeks.

- In the year 2003 Contrarian strategy yields negative returns for all holding periods.

- In the year 2004 Contrarian strategy yields negative returns for all holding periods.

- In the year 2005 Contrarian strategy yields positive returns for the holding periods of 1-3 weeks. The result is not statistically significant for any holding period.

- In the year 2006 Contrarian strategy yields positive returns for the holding periods of $1-10$ weeks. The result is statistically significant only for holding period I week. 


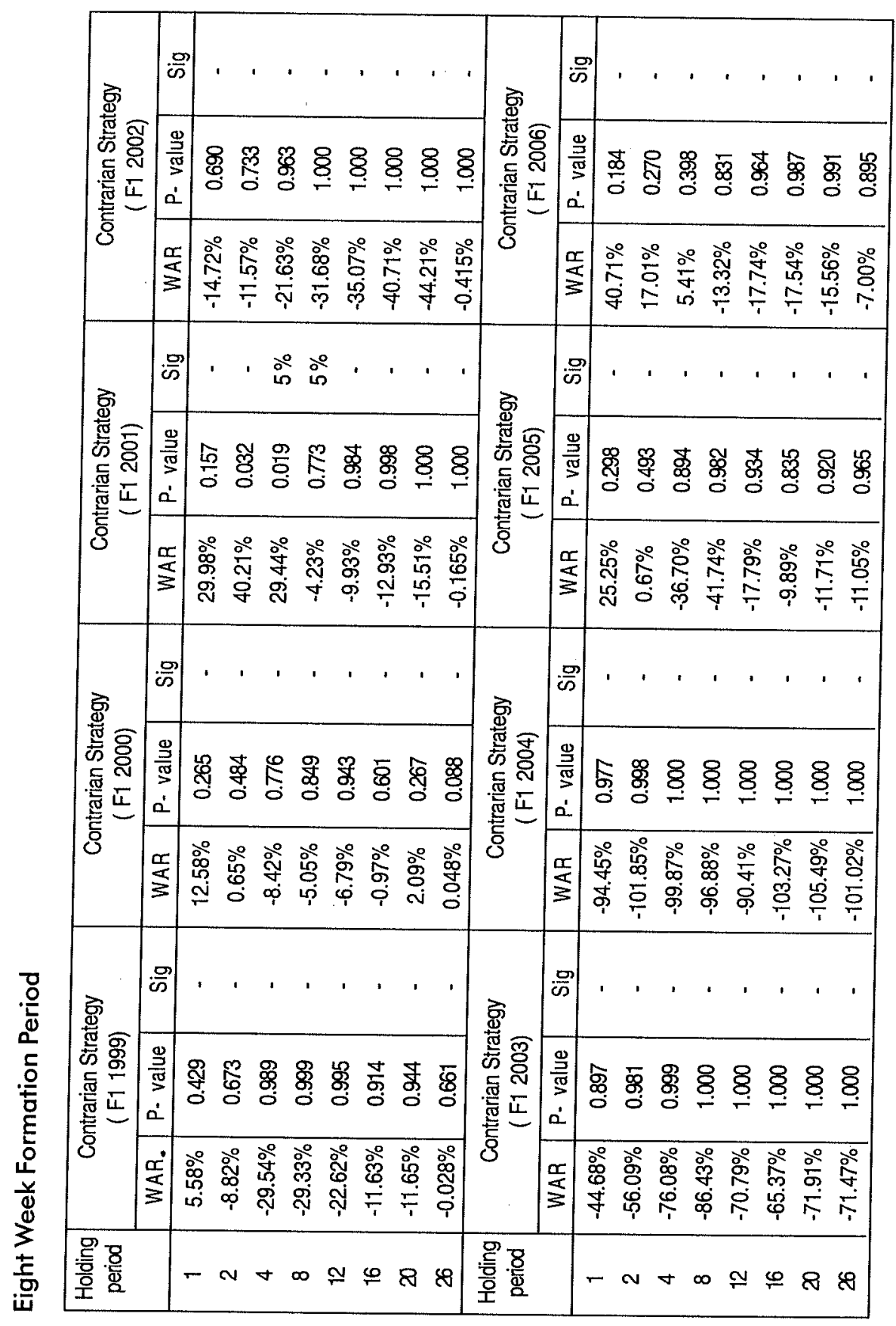


- In the year 1999 Contrarian Strategy yields positive returns only for holding period of 1 week and it is not statistically significant.

- In the year 2000 Contrarian Strategy yields positive returns only for holding period of 1-2 and 17-26 weeks. But the result is not statistically significant for any holding period.

- In the year 2001 Contrarian Strategy yields positive returns only for holding period of $1-6$ weeks. The result is statistically significant for holding period 2-4 weeks.

- In the year 2002 Contrarian Strategy yields negative returns for all holding periods.

- In the year 2003 Contrarian Strategy yields negative returns for all holding periods.

- In the year 2004 Contrarian Strategy yields negative returns for all holding periods.

- In the year 2005 Contrarian Strategy yields positive returns only for holding period of $1-2$ weeks. The result is not statistically significant for any holding period.

- In the year 2006 Contrarian Strategy yields positive returns only for holding period of 1-4 weeks. The result is not statistically significant for any holding period.

\section{Proportion Test for Momentum Strategy}

T-test is done on the results obtained for different formation periods and holding period. Following hypotheses have been tested

$H_{0}$ : Proportion of weeks for which momentum returns are observed is $50 \%$

$\mathrm{H}_{1}$ : Proportion of weeks for which momentum returns are observed is greater than $50 \%$ 


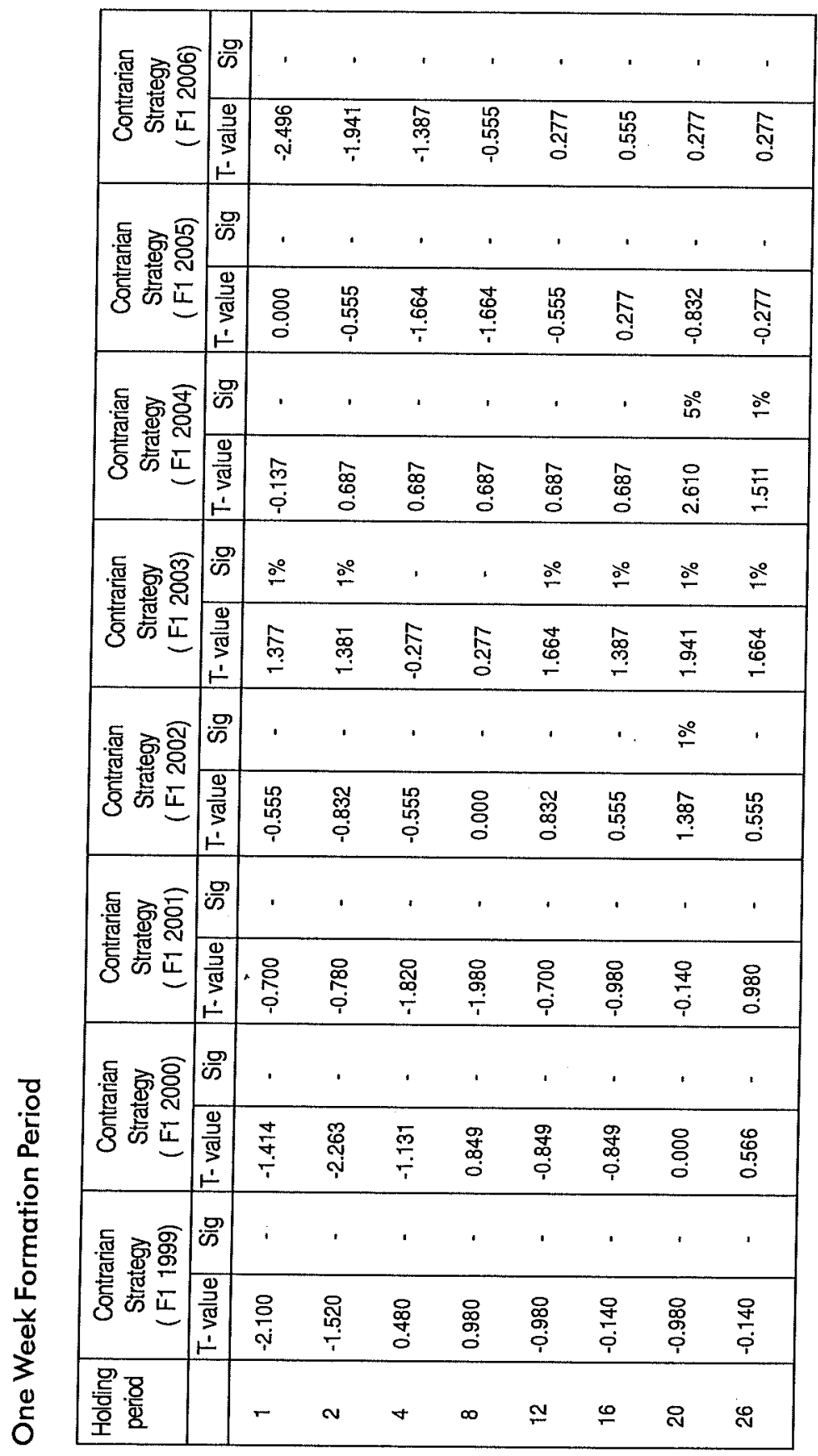


- In the year 1999 momentum strategy is profitable for greater number of weeks only for holding periods of 4,7,17 and 25 weeks but it is not statistically significant for any holding period.

- In the year 2000 momentum strategy is profitable for greater number of weeks only for holding periods of 24,25 and 26 weeks but it is not statistically significant for any holding period.

- In the year 2001 momentum strategy is profitable for greater number of weeks only for holding periods of 3 and 10-26 weeks. But only the momentum profit for the holding periods 20 and 21 weeks is statistically significant for a higher number of weeks.

- In the year 2002 momentum strategy is profitable for greater number of weeks for all but holding periods of 4 and 6 weeks and is significant statistically for holding periods of $1,2,10,11,12$ and 16-26 weeks.

- In the year 2003 momentum strategy is profitable for greater number of weeks for all but holding periods of 1 and 6 weeks and is statistically significant for holding periods of 10,20,21,23 and 26 weeks.

- In the year 2004 momentum strategy is profitable for greater number of weeks for all but holding periods of 10,16 and 25 weeks but is not statistically significant for any holding periods.

- In the year 2005 momentum strategy is profitable for greater number of weeks for all but holding periods of $12,15,16$ and $20-26$ weeks but is not statistically significant for any holding periods.

- In the year 2006 momentum strategy is profitable for greater number of weeks for all but holding periods of 13,15 and 25 weeks but is not statistically significant for any holding periods. 


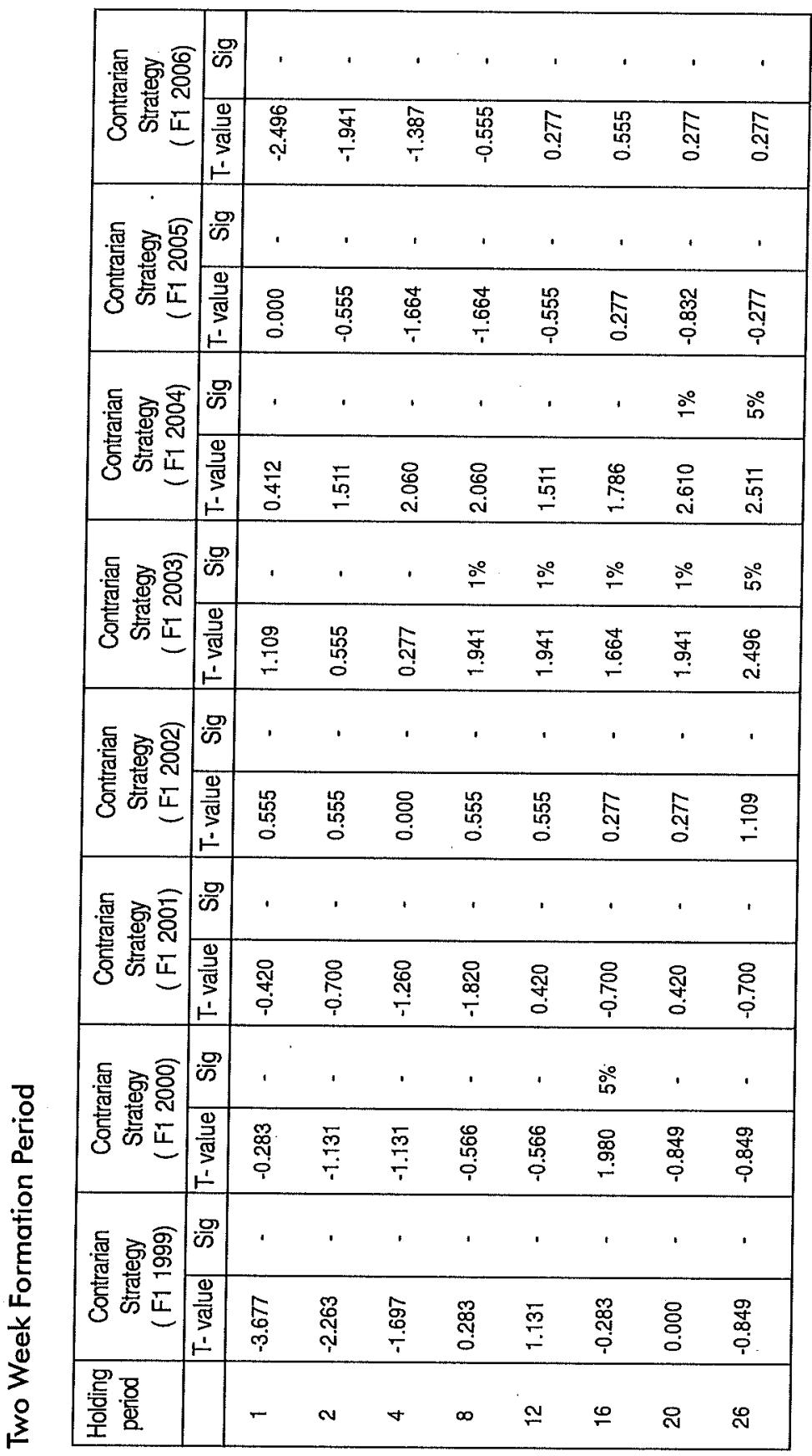


- In the year 1999 Momentum strategy is profitable for greater number of weeks for holding periods of $7-15$ weeks. But it is not statistically significant for any holding period.

- In the year 2000 Momentum strategy is profitable for greater number of weeks for holding periods of 14-18 weeks. But it is not statistically significant only for a holding period of 16 weeks.

- In the year 2001 Momentum strategy is profitable for greater number of weeks for holding periods of 11,12 and 20-24 weeks. But it is not statistically significant for any holding period.

- In the year 2002 momentum strategy is profitable for greater number of weeks for all but holding periods of 3-7, 9, 17 and 18 weeks. But only the momentum profit for holding periods 25 weeks is statistically significant for higher number of weeks.

- In the year 2003 momentum strategy is profitable for greater number of weeks for holding periods of 5 and 6 weeks. It is not statistically significant only for holding period of 8-13 weeks and 15-26 weeks.

- In the year 2004 momentum strategy is profitable for greater number of weeks for all holding periods but for the holding period of 5 weeks. The result is statistically significant for holding period of 2-4 weeks, 7-13 weeks and $16-26$ weeks.

- In the year 2005 momentum strategy is profitable for greater number of weeks for holding periods of 5,7 and 9 weeks and that too is not statistically significant.

- In the year 2006 momentum strategy is profitable for greater number of weeks for holding periods of 9 and 12-26 weeks. The result is statistically significant for holding periods of 13-16 weeks. 


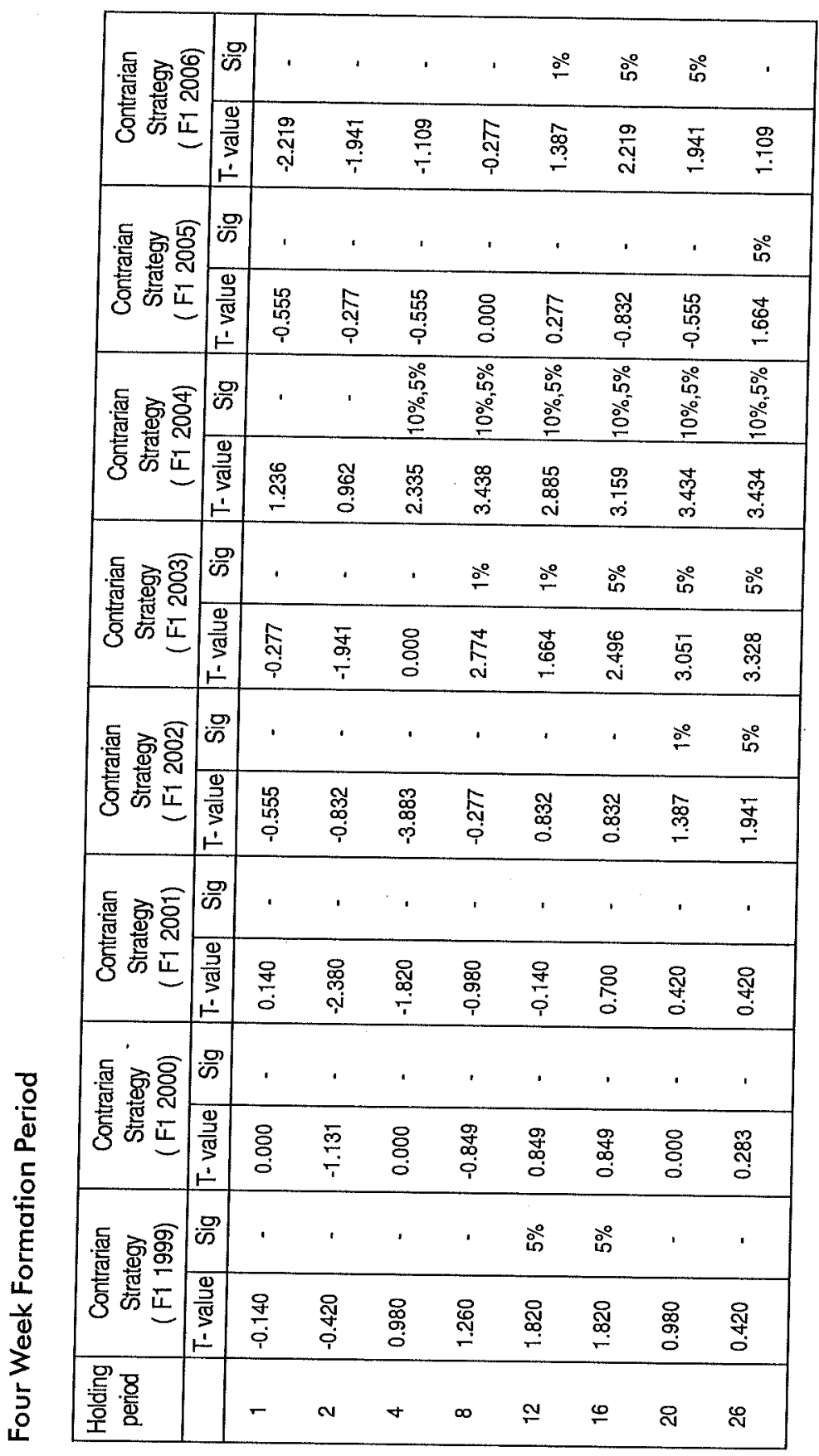


- In the year 1999 Momentum strategy is profitable for greater number of weeks for all but holding periods of 1,2,3 and 25 weeks. The results are statistically significant for holding periods of 6,7,9-16 and 22 weeks.

- In the year 2000 Momentum strategy is profitable for greater number of weeks for all but holding periods of $2,6,7,8,9,17,18$ and 19 weeks. The results are not statistically significant for any holding periods.

- In the year 2001 Momentum strategy is profitable for greater number of weeks for holding periods of 1,11 and 15-26 weeks. But only the momentum profit for holding periods 19 and 21 weeks is statistically significant for a higher number of weeks.

- In the year 2002 Momentum strategy is profitable for greater number of weeks for holding periods of 12-26 weeks. The results are statistically significant for any holding periods of 19-26 weeks.

- In the year 2003 Momentum strategy is profitable for greater number of weeks for all but holding periods of $1-4$ weeks. The results are statistically significant for any holding period of 6-26 weeks.

- In the year 2004 Momentum strategy is profitable for greater number of weeks for all holding periods. The results are statistically significant for holding periods of 3-26 weeks.

- In the year 2005 Momentum strategy is profitable for greater number of weeks holding periods of $9-15$ and 22-26 weeks. The results are not statistically significant for any holding period of 10,11 and 26 weeks.

- In the year 2006 Momentum strategy is profitable for greater number of weeks for holding periods of 7.-26 weeks and are statistically significant for 12-16 weeks and 18-24 weeks. 


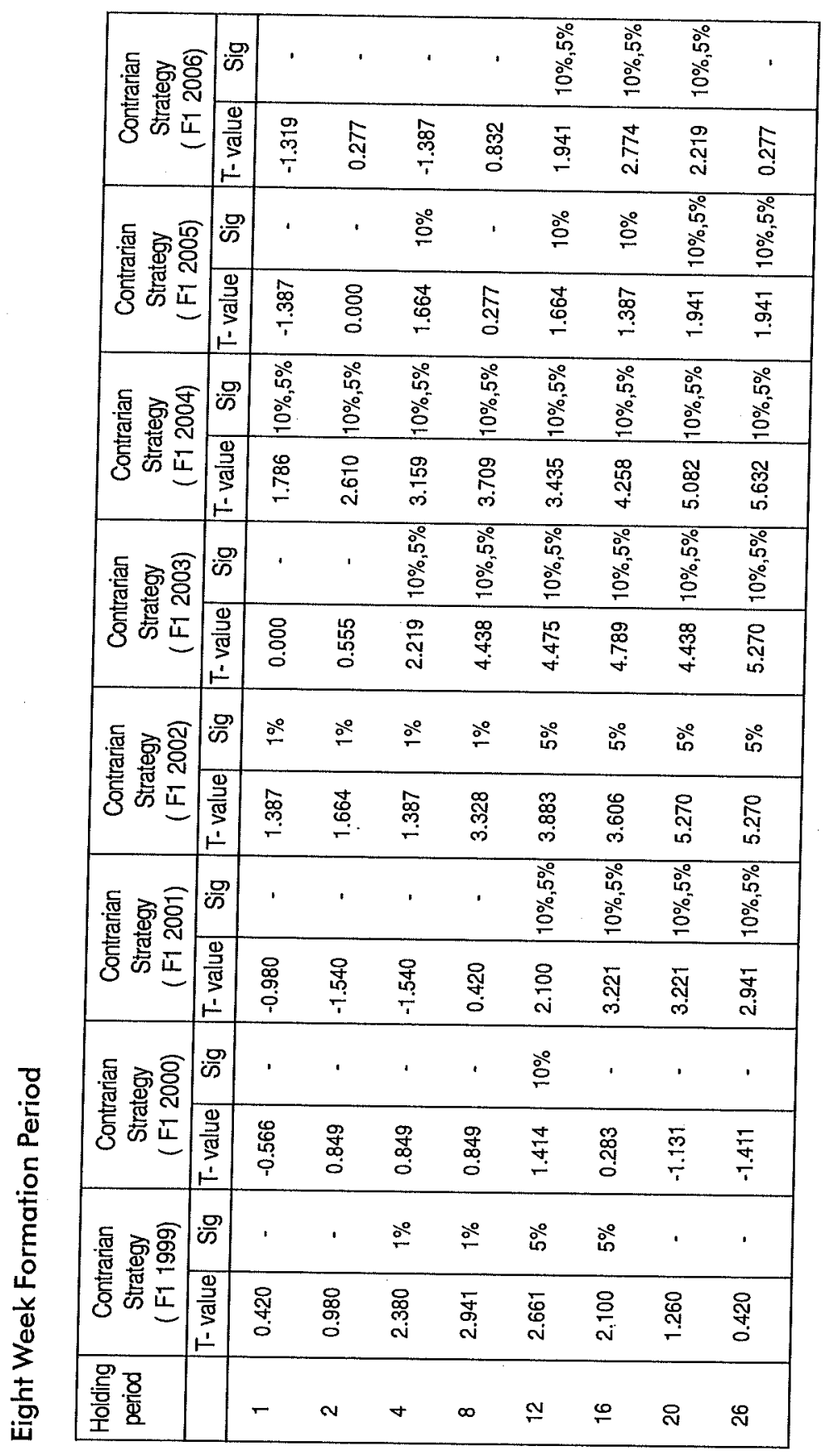


- In the year 1999 momentum strategy is profitable for greater number of weeks for all the holding periods. The results are statistically significant for a holding period of $3-19$ and 22 weeks.

- In the year 2000 momentum strategy is profitable for greater number of weeks for all but the holding periods of 1 and 18-26 weeks. The results are statistically significant for a holding period of $9-13$ weeks.

- In the year 2001 momentum strategy is profitable for greater number of weeks for all but the holding periods of $1-5$ weeks. The results are statistically significant for a holding period of $11-26$ weeks.

- In the year 2002 momentum strategy is profitable for greater number of weeks for all the holding periods. The results are statistically significant for all but holding period of 3 and 5 weeks.

- In the year 2003 momentum strategy is profitable for greater number of weeks for all but the holding periods of 1 week. The results are also statistically significant for all holding period of 1 and 2 weeks.

- In the year 2004 momentum strategy is profitable for greater number of weeks for all the holding periods. The results are also statistically significant for all holding periods.

- In the year 2005 momentum strategy is profitable for greater number of weeks for all the holding periods. The results are statistically significant for all holding periods.

- In the year 2006 momentum strategy is profitable for greater number of weeks for all but the holding periods of 7-26 weeks. The results are statistically significant for the holding period of 9 and 11-24 weeks.

\section{Mean Test for Momentum Strategy}

Z-test is done on the results obtained for different formation periods and holding period. Following hypotheses have been tested.

$H_{0}$ : Weekly annualized momentum returns are zero

$H_{1}$ : Weekly annualized momentum returns are greater than zero. 


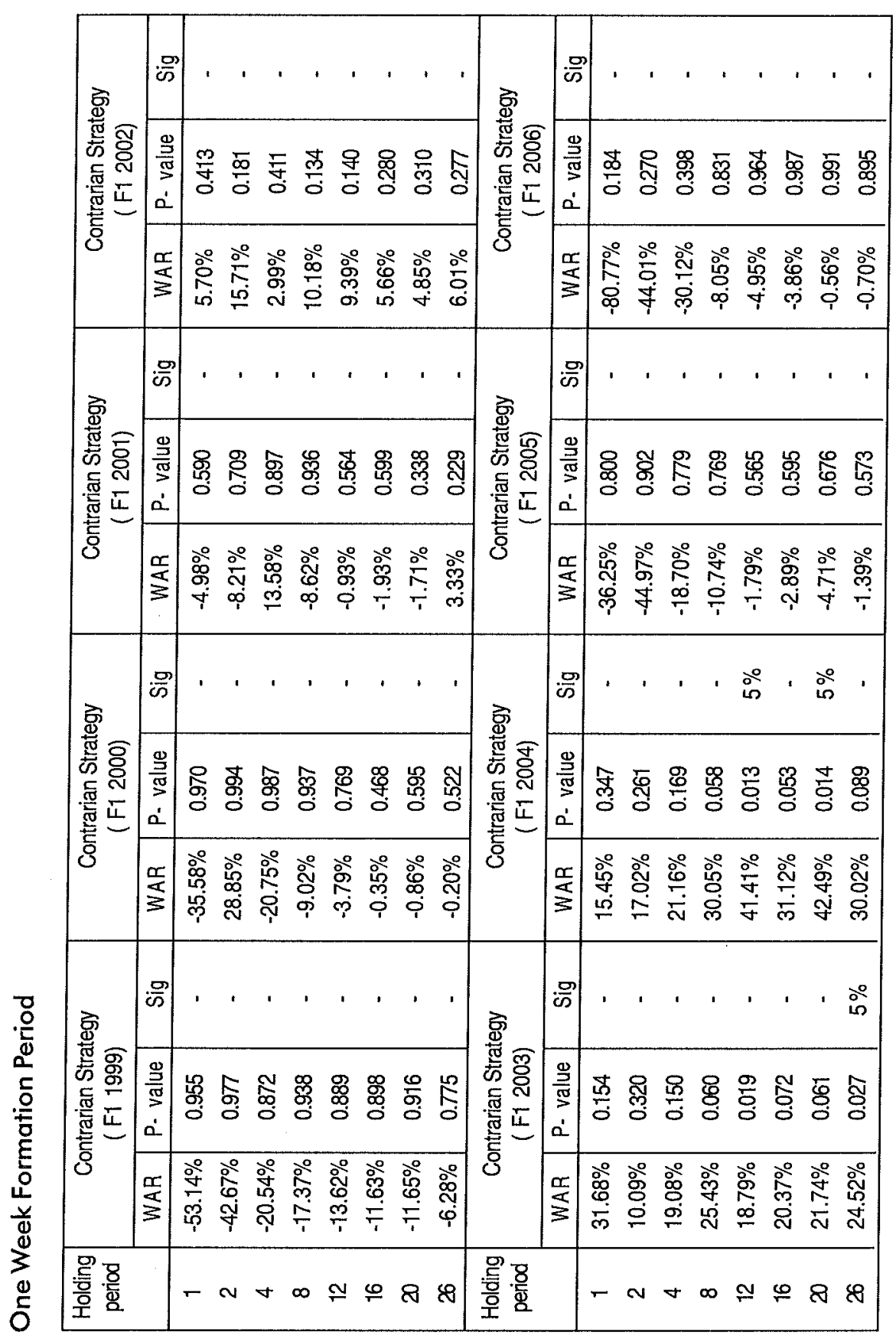


- In the year 1999 momentum strategy yields negative returns for all holding periods.

- In the year 2000 momentum strategy yields positive returns only for holding period of 17 weeks. But the result is statistically not significant.

- In the year 2001 momentum strategy yields positive returns for holding periods of 18-26 weeks. But the results are not statistically significant for any holding period

- In the year 2002 momentum strategy yields positive returns for all holding periods. But the results are not statistically significant for any holding period.

- In the year 2003 momentum strategy yields positive returns for all holding periods. But the results are statistically significant for holding periods of 10 and 23-26 weeks.

- In the year 2004 momentum strategy yields negative returns for all holding periods. But the results are statistically significant only for holding periods of $9-13,15$ and $18-24$ weeks.

- In the year 2005 momentum strategy yields negative returns for all holding periods

- In the year 2006 momentum strategy yields positive returns for holding periods of $15,16,17$ and 26 weeks. But the results are not statistically significant for any holding period. 


\begin{tabular}{|c|c|c|c|c|c|}
\hline \multirow{3}{*}{ 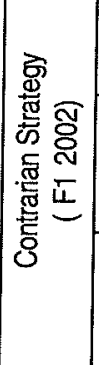 } & के & . & \multirow{3}{*}{ 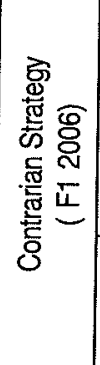 } & के & 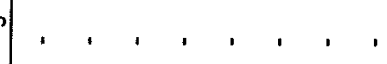 \\
\hline & \multirow{2}{*}{ 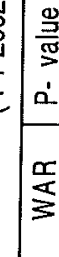 } & 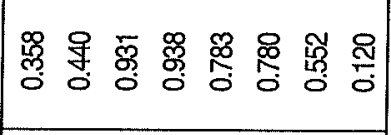 & & $=$ & 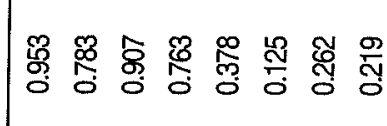 \\
\hline & & 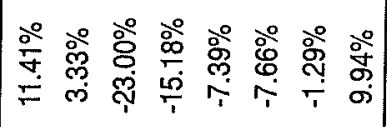 & & $\frac{\alpha}{4}$ & 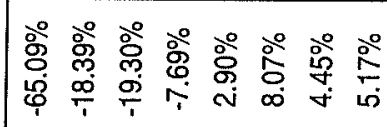 \\
\hline \multirow{3}{*}{ 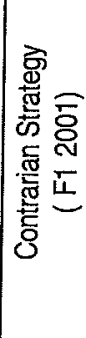 } & in & . & \multirow{3}{*}{ 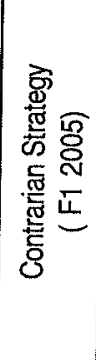 } & $\because 8$ & . \\
\hline & \multirow{2}{*}{$\frac{5}{5}$} & 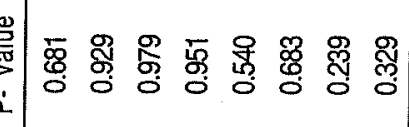 & & $\frac{\substack{9 \\
\frac{9}{3}}}{3}$ & 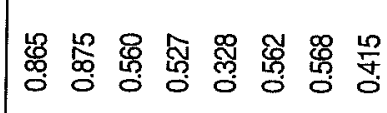 \\
\hline & & 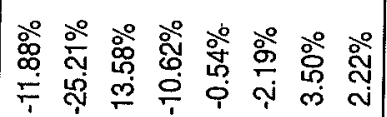 & & $\frac{\frac{\alpha}{3}}{3}$ & 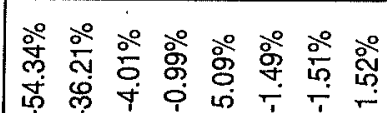 \\
\hline & का & & & i & 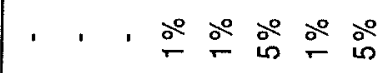 \\
\hline $\mid$ & 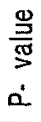 & 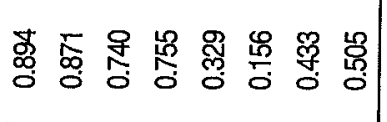 & 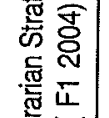 & 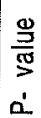 & 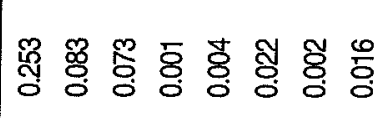 \\
\hline 8 & $\frac{\pi}{4}$ & 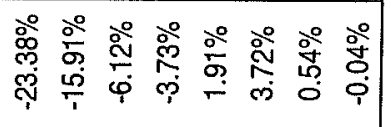 & 8 & $\frac{\pi}{4}$ & 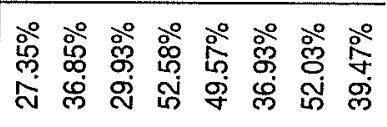 \\
\hline & :क्ष & & 家 & के & . . . . 웅 \\
\hline 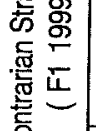 & $\left|\frac{\mathrm{g}}{\mathrm{g}}\right|$ & 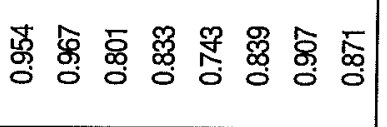 & 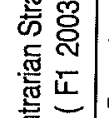 & 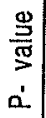 & 帝 兽 \\
\hline 8 & $\begin{array}{l}\frac{\pi}{\alpha} \\
3\end{array}$ & 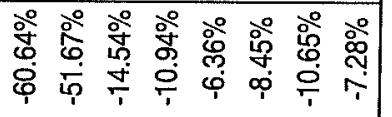 & $\overline{0}$ & $\frac{\alpha}{3}$ & 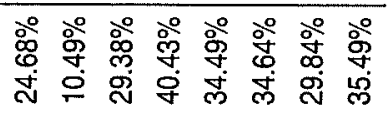 \\
\hline 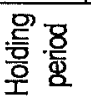 & & $-N+\infty$ & 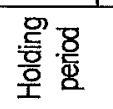 & & $-\sim+\infty \cong ⿻ \&$ \\
\hline
\end{tabular}


- In the year 1999 Momentum Strategy yields negative returns for all holding period.

- In the year 2000 Momentum strategy yields positive returns for all holding periods of $1-4,7-9,11,21$ and 26 weeks. But the result is not statistically significant for any holding period.

- In the year 2001 momentum strategy yields positive returns for holding periods of 17-26 weeks. But the result is not statistically significant for any holding period.

- In the year 2002 momentum strategy yields positive returns for holding periods of 1-2 and 21-26 weeks. But the result is not statistically significant for any holding period.

- In the year 2003 momentum strategy yields positive returns for all holding periods. But the results are statistically significant for holding period 7-26 weeks.

- In the year 2004 momentum strategy yields positive returns for all holding periods. But the result is not statistically significant for holding periods of 5-26 weeks.

- In the year 2005 momentum strategy yields positive returns for holding periods of $9-13$ and $23-26$ weeks. But the result is not statistically significant for any holding period.

- In the year 2006 momentum strategy yields positive returns for holding periods of 12-26 weeks. But the result is not statistically significant for any holding period. 


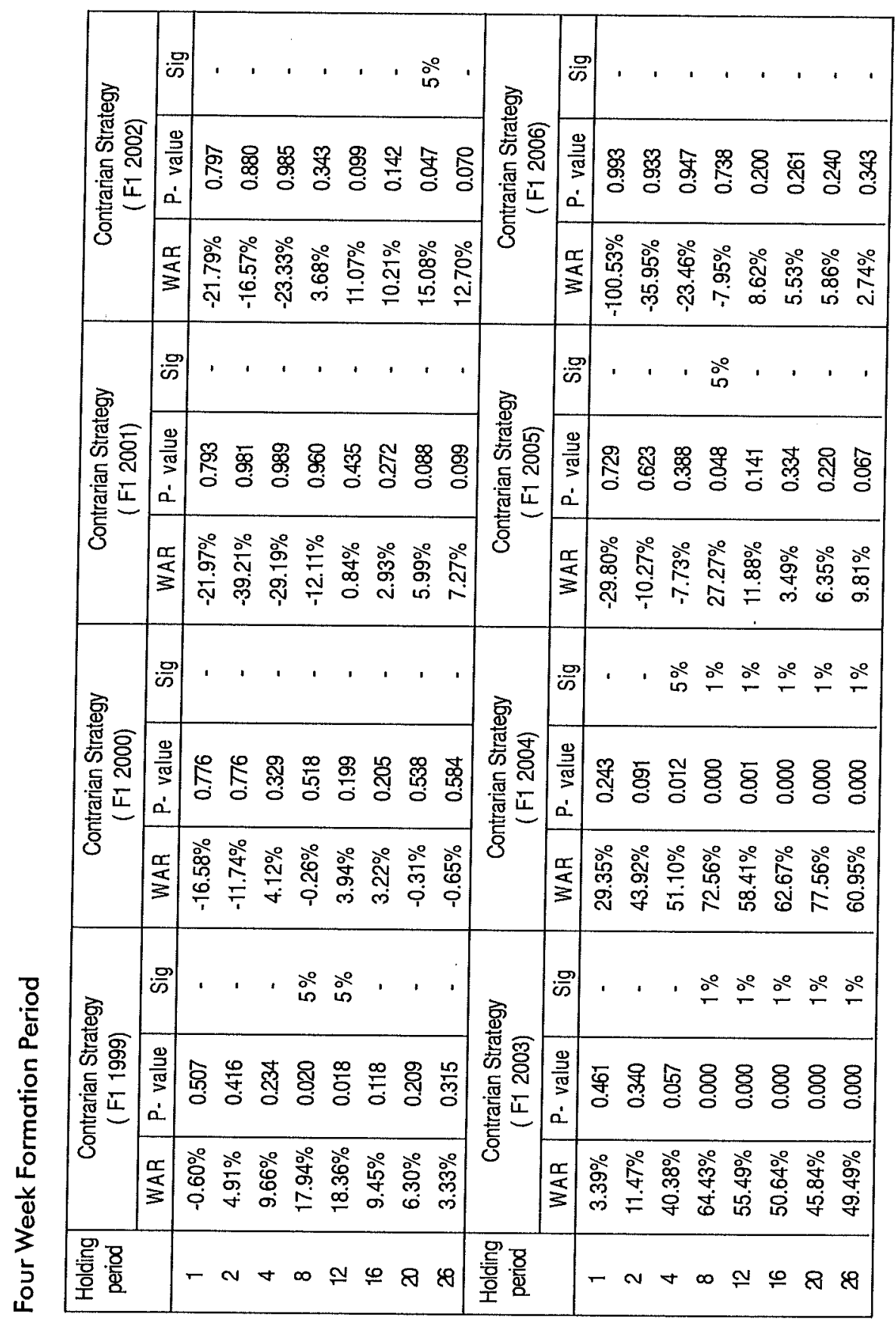


- In the year 1999 Momentum strategy yields positive returns for all holding period of 1 week. The result is statistically significant for holding period of 8.13 weeks.

- In the year 2000 Momentum strategy yields positive returns for all but holding period of $1-3,8,19,20,24,25$ and 26 weeks. But the result is not statistically significant for any holding periods.

- In the year 2001 Momentum strategy yields positive returns for all but holding period of $1-10,13,14$ weeks. But the result is not statistically significant for any holding periods.

- In the year 2002 Momentum strategy yields positive returns for all but holding period of $8-26$ weeks. The result is statistically significant for only holding periods of 20,24 and 25 weeks.

- In the year 2003 Momentum strategy yields positive returns for all holding periods. The result is statistically significant only for any holding period of 20,24 and 25 weeks.

- In the year 2004 Momentum strategy yields positive returns for all holding periods. But the result is statistically significant only for holding periods of holding periods 5-26 weeks.

- In the year 2005 Momentum strategy yields positive returns for all holding periods. But the result is statistically significant only for holding periods of holding periods 3-26 weeks.

- In the year 2006 Momentum strategy yields positive returns for all but holding periods of $11-26$ weeks. But the result is not statistically significant for any holding period. 


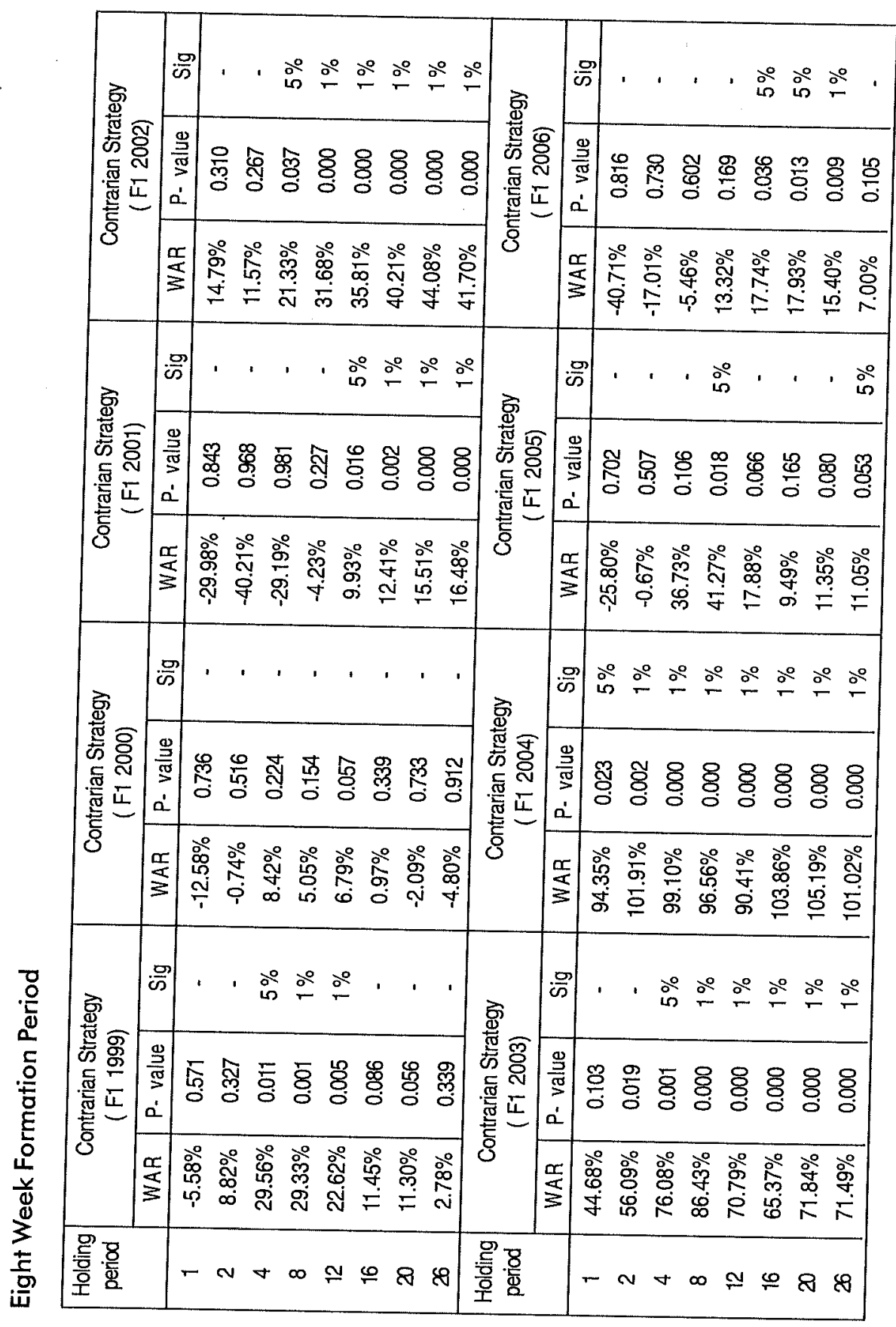


- In the year 1999 Momentum Strategy yields positive returns for all holding period of 1 week. The result is statistically significant for holding period of 4.13 weeks.

- In the year 2000 Momentum Strategy yields positive returns for all holding periods of 3-16 weeks. bUt the result is not statistically significant for any holding period.

- In the year 2001 Momentum Strategy yields positive returns for all holding period of $1-6$ week. The result is statistically significant for holding period of $11-26$ weeks.

- In the year 2002 Momentum Strategy yields positive returns for all holding period of 1 week. The result is statistically significant for holding period of $4-26$ weeks.

- In the year 2003 Momentum Strategy yields positive returns for all holding periods. The result is statistically significant for holding period of 2-26 weeks.

- In the year 2004 Momentum Strategy yields positive returns for all holding period. The result is statistically significant for all holding periods.

- In the year 2005 Momentum Strategy yields positive returns for all but holding periods of $1-2$ weeks. The result is statistically significant for holding periods of 5-11,21 and 23-26 weeks.

- In the year 2006 Momentum Strategy yields positive returns for all holding period of $1-4$ weeks. The result is statistically significant for holding period of 12-23 weeks.

\section{Conclusion}

The summary results for contrarian and momentum strategy have been presented earlier. It is evident from the results that contrarian strategy doesn't

yield statistically significant profits at a significance level of $5 \%$ for any combination of formation period and holding period under study.

Momentum strategy on the other hand results in statistically significant profits at a significance level of $5 \%$. For formation period of one-week 
momentum strategy results in statistically significant level of profits for holding period of 20 and 26 weeks. For formation period of two weeks

momentum strategy results in statistically significant profits for holding periods of $8,12,16,20,26$ weeks. For the formation period of eight weeks

momentum strategy results in statistically significant profits for holding period of $2,4,8,12,16,20$ and 26 weeks.

Existence of momentum profits for the period under study (1999-2006) indicates market inefficiency. Analysis of momentum strategy over a larger period can lead to make a conclusive judgment about the efficiency of Indian Stock Market.

\section{Bibliography}

1. Albert, Robert L Jr. and Glenn V Henderson, 1995, Firm Size, Overreaction and Return Reversals, Quarterly Journal of Business and Economics, 34, 60-81.

2. Asness, Clifford S., John M. Liew and Ross L. Stevens, 1996, Parallels between the cross-sectional predictability of stock returns and country returns, Working paper, Goldman Sachs Asset Management.

3. Ball R., Kothari S., and Shanken J., 1995, Problems in measuring portfolio performance: An application to contrarian investment strategies, Journal of Financial Economics, 38: 79-107.

4. Barber B., and Lyon J., 1997, Detecting long-horizon abnormal stock returns: the empirical power and

5. specification of test statistics, Journal of Financial Economics: 43: $341-378$.

6. Basu, S., 1983, The relationship between earnings yield, market value, and return for NYSE common stocks, Journal of Financial Economics, 12. 129-156.

7. Chan, Louis K., Narasimhan Jegadeesh, and Josef Lakonishok, 1996, Momentum strategies, Journal of Finance 51, 1681-1713.

8. Chang, Rosita P, D. W. Mcleavey and S. Ghon Rhee, 1995, Short-term abnormal returns of the contrarian strategy in the Japanese stock market, Journal of Business Finance \& Accounting 22 Oxford, 1035-1049.

9. Chui, Andy, Sheridan Titman, and K.C. John Wei, 2000, Momentum, ownership structure, and financial crises: An analysis of Asian stock markets. Working paper, University of Texas at Austin. 
10. Clearly, Sean and Michael Inglis, Momentum in Canadian Stock Returns, Canadian Journal of Administrative Sciences, 15-3, 279-291

11. Grundy, Bruce D., and J. Spencer Martin, 1998, Understanding the nature of risks and the sources of rewards to momentum investing, Working Paper, the Wharton School.

12. Hong, Harrison, and Jeremy C. Stein, 2000, Bad news travel slowly: Size, analyst coverage, and the profitability of momentum strategies, Journal of Finance 48,65 . 91.

13. Jegadeesh Narasimhan, and Sheridan Titman, 2001, Profitability of Momentum Strategies : An Evaluation of Alternative Explanations, The Journal of Finance 56, 699-720.

14. Korkie, R. and J. Plas, 1995, Back to reality: Another look at share price momentum strategies, Working Paper, University of Alberta.

15. Lakonishok J., Shleifer A., and Vishny R., 1994, Contrarian Investment, extrapolation, and risk, Journal of Finance, 49: 1541-1578.

16. Lee, Charles, and Bhaskaran Swaminathan, 2000, Price momentum and trading volume, Journal of Finance 55, $2017-2069$.

17. Lo, Andrew W., and A Craig MacKinlay, 1990, When are contrarian profits due to stock market over reaction?, Review of Financial Studies 3, 175-208.

18. $\mathrm{O}^{\prime}$ Neal, Edward S, 2000, Industry Momentum and Sector Mutual Funds, Financial Analysts Journal 56, 37-49.

19. Rouwenhorst, K. Geert, 1998, International momentum strategies, Journal of Finance $53,267-284$.

20. White, Derek R. and John Okunev, 2001, Do Momentum Strategies Still Work in Foreign Currency Markets?, Working Paper, University of South Wales, Social Science Research Network Electronic Library. 